\title{
Coevolution of Leukemia and Host Immune Cells in Chronic Lymphocytic Leukemia
}

\author{
Noelia Purroy ${ }^{1,2,3}$ and Catherine J. $\mathrm{Wu}^{1,2,3,4}$ \\ ${ }^{1}$ Department of Medical Oncology, Dana-Farber Cancer Institute, Boston, Massachusetts 02215 \\ ${ }^{2}$ Broad Institute of MIT and Harvard, Cambridge, Massachusetts 02142 \\ ${ }^{3}$ Harvard Medical School, Boston, Massachusetts 02115 \\ ${ }^{4}$ Department of Medicine, Brigham and Women's Hospital, Boston, Massachusetts 02115 \\ Correspondence: cwu@partners.org
}

Cumulative studies on the dissection of changes in driver genetic lesions in cancer across the course of the disease have provided powerful insights into the adaptive mechanisms of tumors in response to the selective pressures of therapy and environmental changes. In particular, the advent of next-generation-sequencing (NGS)-based technologies and its implementation for the large-scale comprehensive analyses of cancers have greatly advanced our understanding of cancer as a complex dynamic system wherein genetically distinct subclones interact and compete during tumor evolution. Aside from genetic evolution arising from interactions intrinsic to the cell subpopulations within tumors, it is increasingly appreciated that reciprocal interactions between the tumor cell and cellular constituents of the microenvironment further exert selective pressures on specific clones that can impact the balance between tumor immunity and immunologic evasion and escape. Herein, we review the evidence supporting these concepts, with a particular focus on chronic lymphocytic leukemia $(\mathrm{CLL})$, a disease that has been highly amenable to genomic interrogation and studies of clonal heterogeneity and evolution. Better knowledge of the basis for immune escape has an important clinical impact on prognostic stratification and on the pursuit of new therapeutic opportunities.

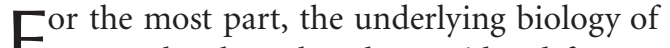
F cancers has been largely considered from a purely cell-autonomous disease point of view. Within this framework, genetic defects accumulate progressively in one (or a few) cells, with the occasional somatic mutation affecting a gene or regulatory element that would drive the cell to preferential growth and escape from signals that would otherwise enforce permanent growth arrest or self-destruction (Hanahan and Wein- berg 2000). Recent next-generation-sequencing (NGS)-based technologies have shown the complex heterogeneous genetic landscapes of tumors and the potential impact of tumor heterogeneity on treatment response and resistance, cancer progression, and the risk of disease relapse (Alexandrov et al. 2013; Lawrence et al. 2013, 2014; Giannakis et al. 2016) (Fig. 1, top). These genomic studies have also provided evidence that tumors evolve through a process of

Editors: Charles Swanton, Alberto Bardelli, Kornelia Polyak, Sohrab Shah, and Trevor A. Graham

Additional Perspectives on Cancer Evolution available at www.perspectivesinmedicine.org

Copyright (C) 2017 Cold Spring Harbor Laboratory Press; all rights reserved; doi: 10.1101/cshperspect.a026740

Cite this article as Cold Spring Harb Perspect Med 2017;7:a026740 
N. Purroy and C.J. Wu

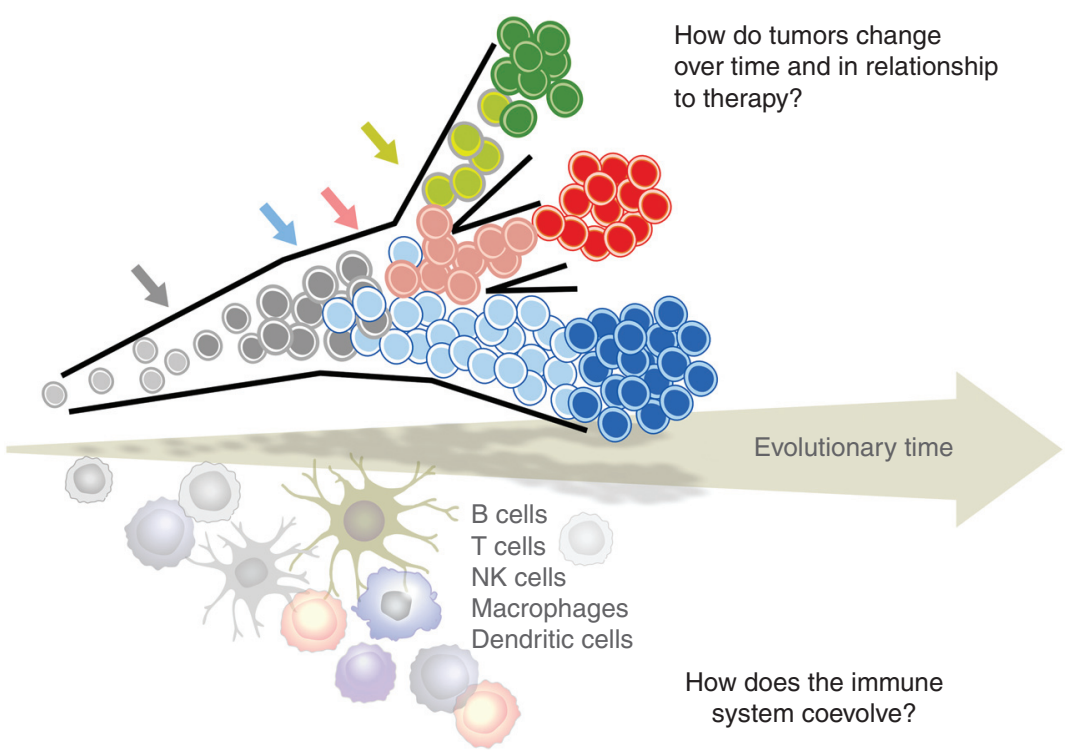

Figure 1. Tumor and immune cells coevolve over time. Arrows denote acquisition of cancer-driving mutations.

clonal evolution, involving genetically distinct subclones that compete over resources and adapt to external pressures (Greaves and Maley 2012; Martincorena et al. 2015).

A direct corollary of this renewed understanding of the role of intratumoral heterogeneity on tumor evolution is an appreciation that successful outgrowth of tumors is also impacted by microenvironmental elements, such as the extracellular matrix, the tumor vascular network, and immune cells (Fig. 1, bottom) (Marusyk et al. 2014). Indeed, immune cellular elements in direct contact with the neoplastic cell have the potential to be protective against cancer through immunosurveillance mechanisms (Smyth et al. 2000; Girardi et al. 2001; Shankaran et al. 2001; Street et al. 2002). In turn, to subvert these physiological immune responses, tumor cells can either generate an immunosuppressive environment or escape from immune recognition (reviewed in Dunn et al. 2002, 2004; Zitvogel et al. 2006). Thus, reciprocal interactions between tumor cells and its microenvironment clearly influence cancer progression, and likely its response to cancer therapy (Fridman et al. 2012; Lion et al. 2012; Kroemer et al. 2015). In parallel with this conceptual shift in mechanisms impacting tumor evolution is the exciting emergence of clinically effective anticancer immunotherapies, which have further shown the potent impact of reestablishing immunological control over neoplastic cells (Schuster et al. 2011; Pardoll 2012; Porter et al. 2015).

In this review, we explore the mechanisms that govern tumor and immune cells coevolution, focusing on studies of chronic lymphocytic leukemia (CLL). Several key features have made CLL an extraordinary model system to assess these questions. First, its relative slow disease progression kinetics has enabled extended longitudinal sampling from individual patients during disease progression and after treatment. Second, highly pure tumor cells are easily accessible from peripheral blood. These unique disease features along with the recent availability and relative affordability of NGS-based technologies have vastly facilitated the evolutionary dissection of the CLL genome over the course of the disease and therapy highlighting the impact of driver events on disease relapse and clinical outcome. Finally, CLL is considered a prototype of a microenvironment-dependent tumor in which neoplastic cells coevolve together with host immune cells within specific tissue microenvironments, such as bone marrow or lymph nodes. Importantly, targeting pathways 
Coevolution of Leukemia and Host Immune Cells

involved in the cross talk between CLL and its microenvironment has already shown potent clinical efficacy (Herman et al. 2013; Brown et al. 2014; O’Brien et al. 2014; Byrd et al. 2015).

\section{CLL: A CLINICAL AND BIOLOGICAL HETEROGENEOUS ENTITY}

CLL, the most common type of adult leukemia in Western countries, is characterized by the proliferation and accumulation of mature
$\mathrm{CD}^{+} \mathrm{CD}^{+}{ }^{+}$B lymphocytes (Chiorazzi et al. 2005). A precursor state to CLL, monoclonal Bcell lymphocytosis (MBL), has been defined as the presence of clonal B cells in peripheral blood in the absence of other features of CLL (Landgren et al. 2009). Conventionally, patients with early-stage CLL are not treated until they become symptomatic or display evidence of rapid disease progression (Fig. 2A). A hallmark of CLL is its striking variable clinical course among patients, with some individuals surviving for

A

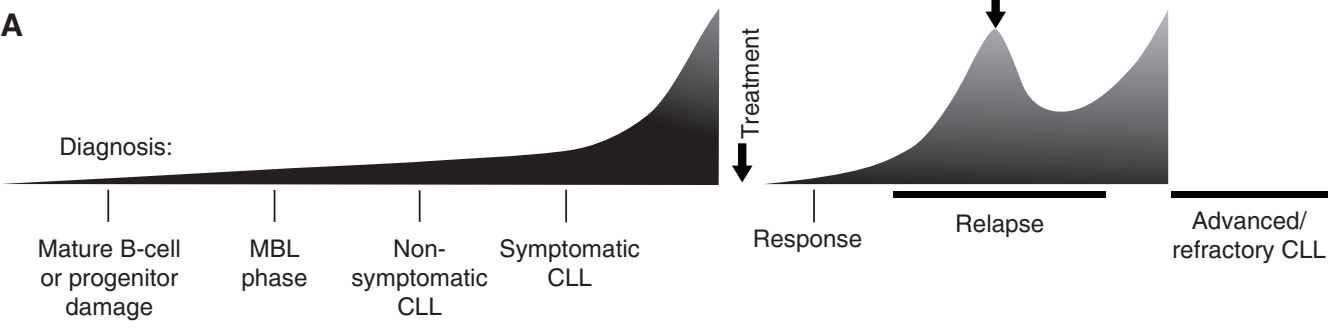

Course of the disease

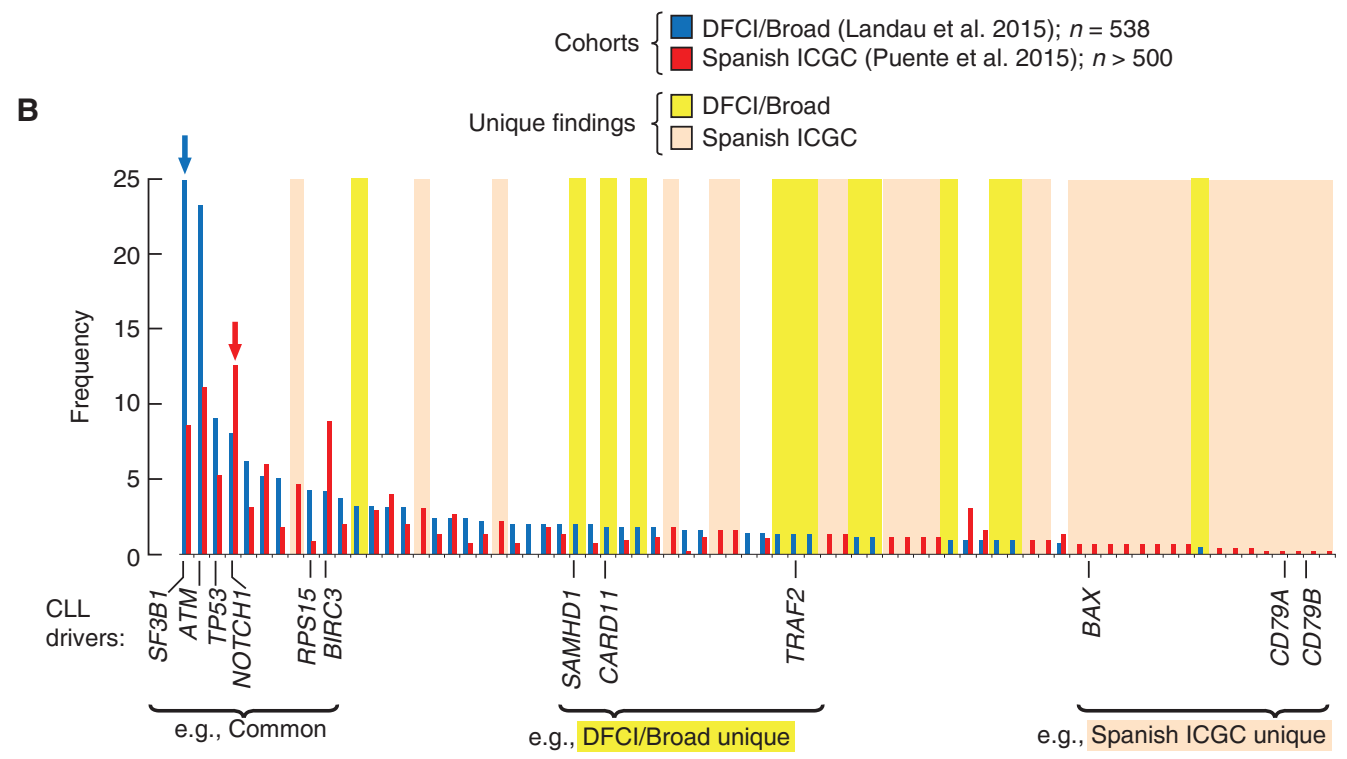

Figure 2. The mutational landscape of chronic lymphocytic leukemia (CLL) evolves with disease progression. (A) A typical CLL disease course. The CLL patient cohorts primarily characterized in Landau et al. (2015) (blue) and Puente et al. (2015) (red) are marked. (B) The frequency of most recurrently mutated genes in these two CLL cohorts, showing the commonalities and differences in genetic findings between the two. CLL, Chronic lymphocytic leukemia; MBL, monoclonal B-cell lymphocytosis; DFCI, Dana-Farber Cancer Institute; ICGC, International Cancer Genome Consortium. 
many years without therapy and eventually succumbing to unrelated illnesses, and with others having a rapidly fatal disease despite diverse aggressive therapies (Chiorazzi et al. 2005).

In addition to its highly variable clinical features, CLL has been also shown to be remarkably heterogeneous from the standpoint of biological characteristics. This heterogeneity is partly reflected by differences in the mutation status of immunoglobulin variable heavy chain $(\mathrm{IgVH})$ genes. According to this criterion, CLL cases can be categorized as having either rare or absence of mutations in the IgVH locus ("unmutated") or as having clonally rearranged $\operatorname{IgVH}$ genes with $2 \%$ or more $\operatorname{IgVH}$ mutations ("mutated" CLL) (Oscier et al. 1997; Fais et al. 1998). Although patients with the latter tend to have a generally indolent course, the former tend to have an aggressive, more rapidly fatal course (Damle et al. 1999; Hamblin et al. 1999). Biologic heterogeneity has also been discerned through the detection of chromosomal aberrations, with $80 \%$ of CLLs carrying at least one of four commonly recurrent events, readily detectable by fluorescence in situ hybridization (FISH) (Döhner et al. 2000). The most common cytogenetic lesion is deletion of chromosome $13 \mathrm{q} 14.3$ (del $[13 \mathrm{q}]$ ), occurring in more than $50 \%$ of cases over time, associated with favorable prognosis. This deleted region contains the DLEU2/MIR15-16 cluster, which regulates Bcell apoptosis and cell cycle (Klein et al. 2010). The other common events, $\operatorname{del}(11 \mathrm{q})$ trisomy 12 and $\operatorname{del}(17 \mathrm{p})$, occur in $18 \%, 16 \%$, and $7 \%$ of patients, respectively. Patients with $\operatorname{del}(17 \mathrm{p})$, which disrupts the expression of the tumor suppressor TP53 (Zenz et al. 2010), or del(11q), which affects the ATM locus (Savitsky et al. 1995), have more advanced disease and more rapid disease progression. Historically, the median time from diagnosis to first treatment in these two groups has been only 9 and 13 months, respectively (Döhner et al. 2000).

\section{GENETIC HETEROGENEITY IN CLL REVEALED BY NGS}

The advent of NGS and the application of whole-exome sequencing (WES) to CLL have transformed our understanding of the genetic heterogeneity of CLL. The earliest studies, studying up to 100 subjects, revealed the high degree of genetic variability among CLL patients, although the overall somatic mutation rate was significantly lower than in solid tumors (Pleasance et al. 2010; Fabbri et al. 2011; Puente et al. 2011; Wang et al. 2011). These studies also highlighted several key somatic mutations in CLL, including the transcription factor $\mathrm{NOTCH} 1$ and the splicing factor $3 \mathrm{~b}$ subunit 1 (SF3B1), enabled the reconstruction of the genetic pathways underlying disease pathogenesis, and revealed the clinical impact of genetic events (Wang et al. 2011; Quesada et al. 2012).

Over time, as a growing collection of sample cohorts have been studied worldwide (reviewed in Guièze and Wu 2015), variation in the detection of somatic mutations and their frequencies has been observed, and can be attributed to (1) limited size of any single cohort that has impeded an effective statistical inference of cancer drivers; (2) differences in cohort composition with respect to their clinical and biological features; and (3) the relative lack of longitudinal sampling and thus a diminished ability to delineate the complex network among driver genes over the course of the disease and therapy. Two recent seminal studies have largely addressed these challenges (Fig. 2B) (Landau et al. 2015; Puente et al. 2015). Both studies sequenced whole exomes or genomes from more than 500 CLL-normal pairs, thus providing highly comprehensive characterizations of CLL. The clinicobiologic features of the two studies were notably distinct. Landau et al. included matched pretreatment and relapse samples from subjects enrolled on the phase-III CLL8 study of the German CLL Study Group (GCLLSG) and who were treated with the combination of fludarabine and cyclophosphamide, with or without rituximab as first-line therapy (Landau et al. 2015). In contrast, Puente et al. studied "earlier" CLL cohorts, more representative of the natural history of CLL and samples from subjects with MBL (Puente et al. 2015). As shown in Figure 2B, both studies identified common CLL mutated drivers but at different frequencies. Although NOTCH1 (12.6\%), ATM (11\%), SF3B1 
(8.6\%), and BIRC3 $(8.8 \%)$ were the most frequently mutated genes detected by Puente et al., mutations in SF3B1 (21\%), ATM (15\%), and TP53 (7\%) were markedly more abundant in the Landau et al. cohort, with reduced frequencies of mutations in NOTCH1 (6\%) and BIRC3 (4\%) (Landau et al. 2015; Puente et al. 2015). The large sample cohorts of these studies have also allowed the discovery of novel candidate cancer genes and, thus, novel cellular processes and pathways affected in CLL.

NGS has been also highly transformative in unraveling intratumoral heterogeneity in CLL by providing a comprehensive approach to the detection of subclones at high resolution and their tracking over time (Schuh et al. 2012). By integrating somatic mutation and copy number alteration data, which enabled estimation of the fraction of cancer cells harboring a mutation, Landau et al. established that certain somatic mutations (i.e., in MYD88, trisomy 12, and $\operatorname{del}[13 \mathrm{q}]$ ) were detected preferentially as clonal events while others (SF3B1 and TP53) as subclonal events, corresponding to earlier and later events in CLL evolution (Landau et al. 2013). These have been consistent findings within the recently characterized larger sample cohorts that have enabled the generation of network models (Wang et al. 2014a; Landau et al. 2015). Importantly, an increased frequency of subclonal driver events were observed in treated relative to untreated patients, supporting the idea that treatment removes dominant subclones and eliminates competition for growth, thereby allowing for the expansion of one or more fit subclones harboring a higher number of mutated driver genes. Indeed, the studies of the CLL8 cohort showed large clonal shifts between pre- and postchemotherapy relapse samples that were distributed into three main patterns: predominantly stable events (trisomy 12, $\operatorname{del}[13 \mathrm{q}]$, del[11q]), predominantly increasing on relapse (TP53 mutations and $\operatorname{del}[17 \mathrm{p}])$, and shifting cancer cell fractions over time (i.e., ATM, SF3B1, POT1) (Landau et al. 2015). Landau et al. further showed that future evolutionary trajectories were already present in the pretreatment sample in one-third of cases. Notably, these results suggest that, within this therapeutic context, TP53 mutation or $\operatorname{del}(17 \mathrm{p})$ provide the strongest fitness advantage compared to CLL drivers. Throughout these studies, the presence of subclonal driver mutations adversely impacted clinical outcome, underscoring the importance of the evolutionary landscape as the engine driving cancer relapse.

\section{IMPACT OF EPIGENETIC HETEROGENEITY ON CLL CLONAL EVOLUTION}

Together with genetic heterogeneity, epigenetic modifications play a crucial role in cancer development. Methylation status has been the best characterized of epigenetic alterations, and has been the focus of multiple studies in CLL. In particular, the epigenomic landscape of CLL has been characterized to harbor global hypomethylation combined with local hypermethylation, as described in other cancers (Wahlfors et al. 1992; Cahill and Rosenquist 2013; Ziller et al. 2013). By mapping the similarity between CLLs and normal B cells at various stages of differentiation, a recent study revealed a continuum in the spectrum of originating B cells from which malignant transformation has occurred (Oakes et al. 2016), likely contributing to the biologic and phenotypic heterogeneity of this disease. Recently, comprehensive methylation profiling by genome-wide arrays or by massively parallel sequencing-based approaches in CLL has shown vast intratumoral methylation heterogeneity (Kulis et al. 2012; Pei et al. 2012; Landau et al. 2014; Oakes et al. 2014; Puente et al. 2015; Queirós et al. 2015). Increasing methylation heterogeneity has been consistently associated with advanced genetic subclonal complexity over time and across sample cohorts, thus linking genetic and methylome evolution in CLL (Landau et al. 2014; Oakes et al. 2014; Puente et al. 2015). Landau et al. identified that CLL cells have pervasive increased locally disordered methylation compared to normal B cells, and that expression heterogeneity is associated with methylation heterogeneity. This study further suggested that locally disordered methylation creates the potential to enhance the evolutionary adaptive capacity of CLL cells by increasing the background noise of the genome, 
and thereby providing increased opportunities for genetic diversification. In agreement with this notion, an association between methylation evolution and adverse clinical outcome has been repeatedly shown (Landau et al. 2014; Oakes et al. 2014; Puente et al. 2015).

\section{COEVOLUTION OF CANCER AND HOST- IMMUNE CELLS}

Malignant cells are constantly interacting with the immune system even before becoming clinically evident. Understanding the evolutionary capacity of both tumor and immune cells and the selective pressure they mutually exert on each other during cancer development is emerging as a crucial factor in defining cancer trajectories. Conceptually, when these two evolving systems interact, both cell populations experience pressures that reciprocally shape tumor immunogenicity and lead to success or failure of immunosurveillance (Fig. 3), consistent with the process of cancer immune editing, which consists of three phases: elimination, equilibrium, and escape (Schreiber et al. 2011).
In this process, one can conceive that the tumor, with its expression of tumor-specific antigens, could provoke an antitumor immune response. The mechanisms by which the immune system is alerted to the presence of a developing tumor are not fully understood. It is speculated that among the possibilities are the creation of immunogenic antigens by tumor cells, which together with the release of immunogenic signals by tumor cells (i.e., tumor necrosis factor $\alpha$ [TNF- $\alpha$ ], interleukin 1 [IL-1], and interferon $\alpha$ $[$ IFN- $\alpha]$ ) lead to the priming and induction of effector T cells capable of recognizing these antigens. In turn, this could lead to cytolysis of target tumor cells, also known as the elimination phase. Evidence for the elimination phase in humans comes from the observation of expanded clonal T cells in patients with spontaneously regressing melanoma lesions (Ferradini et al. 1993; Zorn and Hercend 1999); tumor infiltration by $\mathrm{CD}^{+} \mathrm{T}$ cells, natural killer (NK) cells, or natural killer T (NKT) cells has been associated with an improved prognosis for a number of different tumor types (reviewed in Vesely et al. 2011); and immunosuppression has been often associated with increased risk of cancer (re-

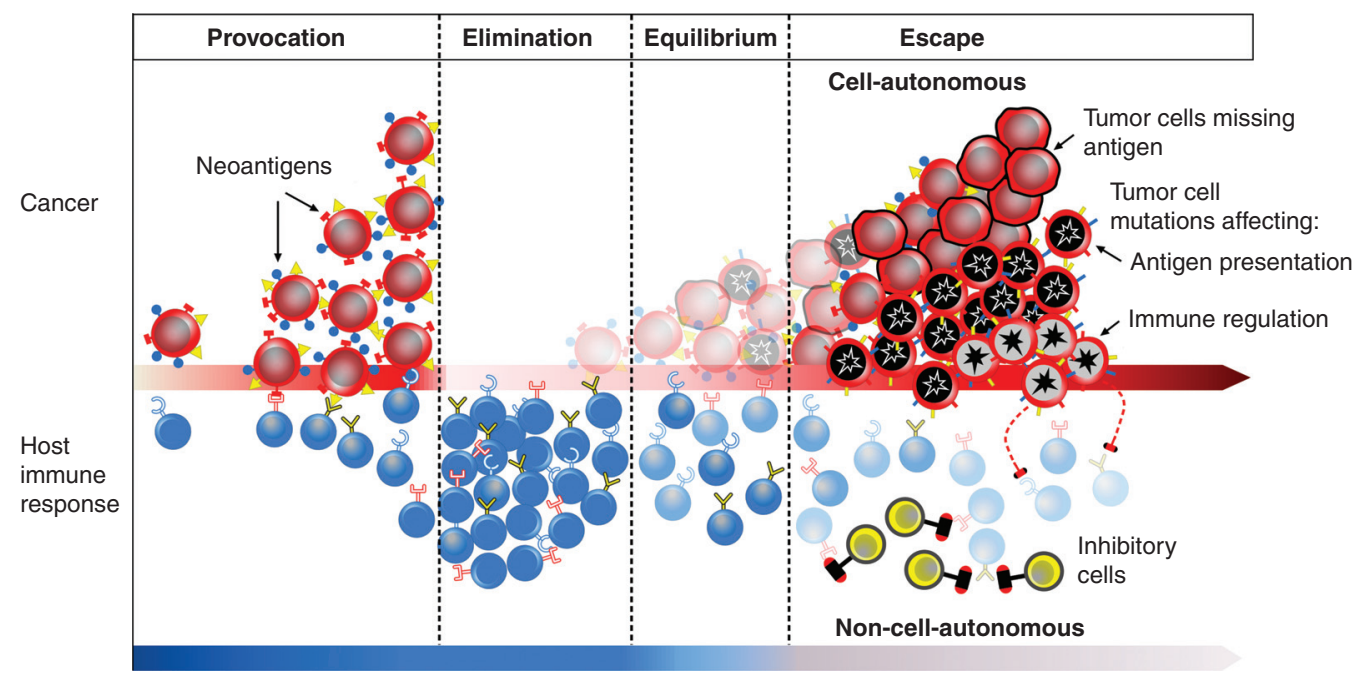

Figure 3. Model of tumor and host immune cell coevolution. Clonal diversification of chronic lymphocytic leukemia (CLL) cells may result from cell-autonomous mechanisms ultimately leading to the emergence of fitter subclones competing within bulk CLL. Host immune cells coevolve with CLL cells by initially creating an antitumor immune response. CLL cells might promote immune evasion mechanisms, such as altered antigen presentation or induction of an immunosuppressive microenvironment. 
viewed in Dunn et al. 2002; Vesely et al. 2011). There is less evidence for the equilibrium phase, during which tumor cells and antitumor response coevolve restraining cancer growth for extended time periods. Critical and opposing roles of IL-23/IL-12 or TNFR1/INF- $\gamma$ in maintaining cancer cells in a state of immune-mediated dormancy have been described (Koebel et al. 2007; Müller-Hermelink et al. 2008; Teng et al. 2012; Ngiow et al. 2013).

As a consequence of persistent immune selection pressure placed on genetically plastic tumor cells, it can be expected that subpopulations of tumor cells circumvent immune recognition and/or destruction leading to tumor progression, which is known as tumor immune escape. As opposed to the equilibrium phase, a myriad of studies have assessed the mechanisms of immune escape in cancer, which can be classified into three categories: (1) reduced immune recognition and immune cell stimulation through down-regulation of the expression of tumor antigens and antigen-presenting machinery or decreased priming of dendritic cells or T cells; (2) up-regulation of resistance mechanisms by increased mutated oncogenes; and (3) establishment of an immunosupressive tumor microenvironment (reviewed in Dunn et al. 2004; Schreiber et al. 2011; Vesely et al. 2011; Teng et al. 2015).

\section{CLL AS A MODEL SYSTEM TO STUDY INTERACTIONS BETWEEN TUMOR AND IMMUNE CELLS THROUGH THE COURSE OF THE DISEASE AND THERAPY}

The process of cancer immunoediting is difficult to assess in humans. Nevertheless, CLL, in which malignant $B$ cells are in direct apposition with other immune components within specialized lymphoid compartments (Klein and DallaFavera 2008), provides an opportunity to study tumor-immune interactions over time. The tight regulation of survival and proliferation of CLL cells by the molecular interactions within lymphoid tissues has been well recognized (Burger et al. 2000; Burger and Kipps 2002). Characteristically, CLL cells residing in lymph nodes
Coevolution of Leukemia and Host Immune Cells

form distinct structures known as pseudofollicles or proliferation centers (Schmid and Isaacson 1994; Sachanas et al. 2013). It has been suggested that these proliferation centers might be the predominant site for clonal expansion of CLL cells (Caligaris-Cappio and Ghia 2008). Accumulating data now suggests that the interplay between leukemic and immune cells is a dynamic process that not only promotes tumor progression and immune escape, but that also shapes the extent to which malignant $\mathrm{B}$ cells are immunogenic and immunostimulatory, as we review below.

\section{The Co-Opting of Normal Immune Functions to Promote CLL}

A common feature of malignant cells is their ability to co-opt normal lineage-specific signaling pathways for their prosurvival benefit. In the case of CLL, these leukemic cells have subverted the B-cell programs of normally transient activation mediated by $\mathrm{B}$-cell receptor (BCR) signaling and immune costimulation in the settings of encounters with cognate antigen or microenvironmental cues (Fig. 4). Indeed, these cellular pathways are constitutively activated in CLL even in the absence of discernible extrinsic ligands, thereby leading to increased cell survival, proliferation, and migration of the malignant cell (Stevenson et al. 2011; Dühren-von Minden et al. 2012; Woyach et al. 2012). The essentiality of activated BCR signaling to CLL pathogenesis has been clearly shown, given the potent clinical responses observed with agents that directly target BCR signaling (Byrd et al. 2013; Brown et al. 2014; Furman et al. 2014; O'Brien et al. 2014). Likewise, the importance of signaling through Toll-like receptors (TLRs) to CLL has been highlighted by the discovery of highly recurrent somatic mutations in CLL in the key adaptor protein MYD88 (Puente et al. 2011; Landau et al. 2013; Martínez-Trillos et al. 2014) that bridges TLRs to the activation of downstream interleukin receptor-activated kinases and the transcription factor NF- $\mathrm{KB}$ (Akira and Takeda 2004; Ngo et al. 2011). The recurrent MYD88 ${ }^{\mathrm{L} 265 \mathrm{P}}$ mutation has been found to drive rapid $\mathrm{B}$-cell proliferation in the absence 


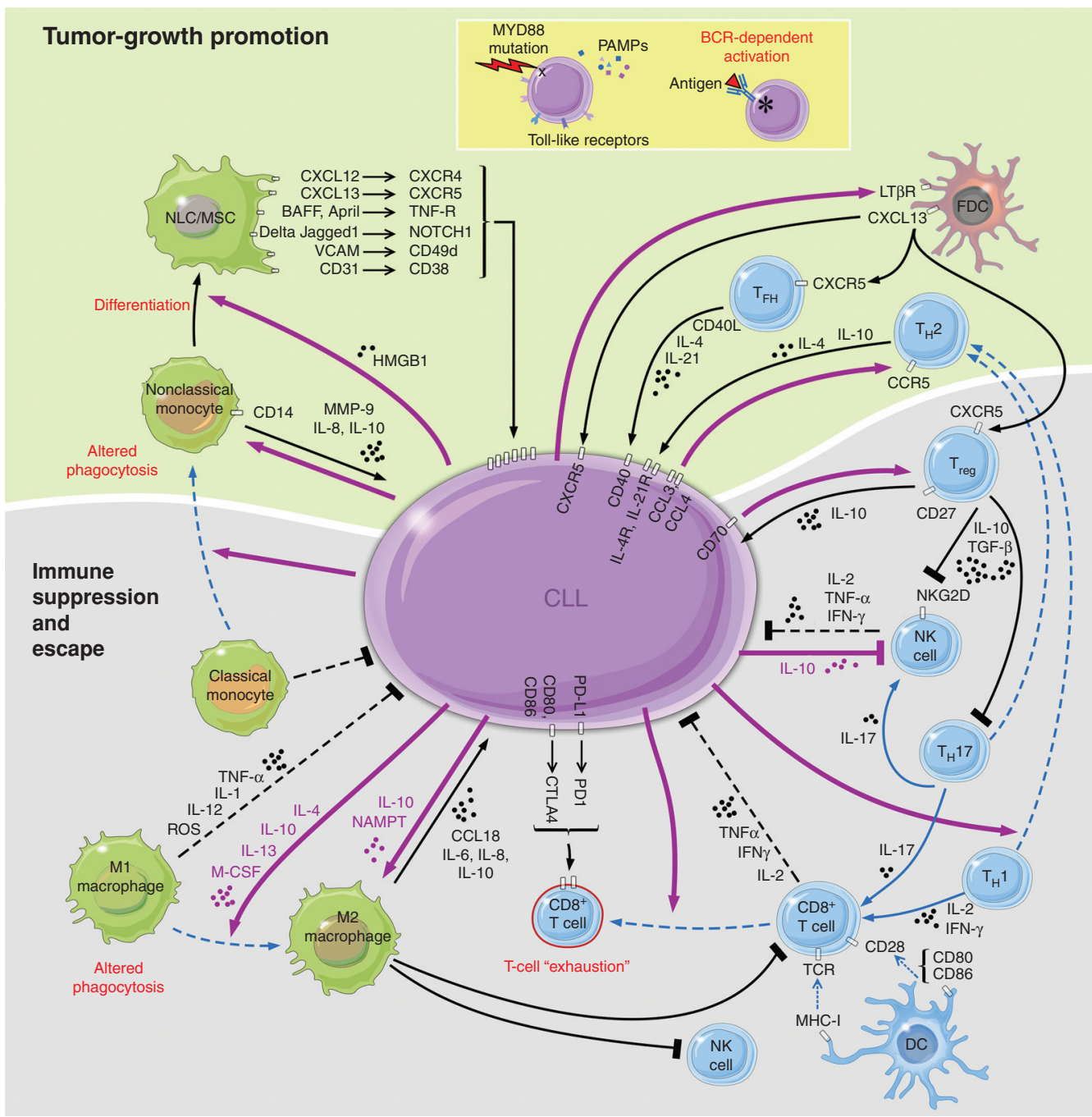

Figure 4. The immune contexture of the tumor microenvironment in chronic lymphocytic leukemia (CLL). Cellular components and mechanisms of tumor-growth promotion, and of immune suppression and escape (magenta arrows, activating signals from CLL cells toward immune cells; black arrows, activating signals from immune cells toward CLL cells; dashed black arrows, mechanisms of immunosurveillance; blue arrows, activating signals between immune cells; dashed blue arrows, mechanisms of immune suppression and escape). NLC, Nurse-like cell; MSC, mesenchymal stromal cell; PAMP, pathogen-associated molecular pattern; TLR, Toll-like receptor; $\mathrm{BCR}, \mathrm{B}$-cell receptor; FDC, follicular dendritic cell; $\mathrm{DC}$, dendritic cell; $\mathrm{T}_{\mathrm{FH}}$, follicular helper $\mathrm{T}$ cell.

of exogenous TLR ligands in activated mature splenic B cells (Wang et al. 2014b).

Aside from this corruption of normal intrinsic B-cell functions to provide progrowth signals for CLL cells, well-characterized reciprocal interactions between CLL cells and multiple immune cell populations have been described, which, in total, drive the secretion of supportive prosurvival and drug-resistance signals. These include (1) mesenchymal stromal cells (MSCs) and monocyte-derived nurse-like cells (NLCs), which secrete the prosurvival chemokines (Bleul et al. 1996; Burger et al. 1999; Möhle et al. 1999; Till et al. 2002; Chunsong et al. 2006; Bürkle et al. 2007), promote tissue retention of CLL cells through interaction with integrins 
(Zucchetto et al. 2009), and are activating to CLL cells through BAFF and APRIL and through interactions with $\mathrm{NOTCH} 1$ and CD38 receptors (Nishio et al. 2005; Zweidler-McKay et al. 2005; Deaglio et al. 2010; Cols et al. 2012); (2) nonclassical monocytes $\left(\mathrm{CD} 14^{\text {low }} \mathrm{CD} 16^{2+}\right)$, which are weakly phagocytic, present at higher levels in CLL patients compared to healthy individuals (Maffei et al. 2013), and are promoted to differentiate into NLCs in vitro (Jia et al. 2014); (3) T-cell populations ( $\mathrm{T}_{\mathrm{FH}}, \mathrm{T}_{\mathrm{H} 2}, \mathrm{~T}_{\mathrm{reg}}$ ), whose close interaction with CLL cells (which secrete CCL3 and CCL4 as potent T-cell chemoattractants) in proliferation centers (Burger et al. 2009) induces the secretion of activation molecules by $\mathrm{T}$ cells (i.e., CD40 ligand, IL-4, and IL-21) (Buske et al. 1997; Granziero et al. 2001; Ghia et al. 2002; Patten et al. 2008; Bagnara et al. 2011; Ahearne et al. 2013; Os et al. 2013); and (4) follicular dendritic cells (FDCs), which are mandatory participants in B-cell development in germinal centers by attracting and retaining antigen-activated $B$ cells and facilitating their clonal expansion within the FDC network in a T-cell-dependent fashion (Liu et al. 1996). FDCs are found in proliferation centers within the lymph node and marrow of CLL patients (Chilosi et al. 1985; Schmid and Isaacson 1994) and protect CLL cells against apoptosis promoting leukemia progression (Pedersen et al. 2002; Heinig et al. 2014).

\section{Immune Suppression and Escape}

Under healthy conditions, the immune system can suppress tumor progression either by destroying tumor cells or by inhibiting their outgrowth, a process also known as cancer immunosurveillance (Mittal et al. 2014). The continuous selection pressure by the immune system placed on genetically unstable tumor cells has a high likelihood of driving the development of resistance mechanisms to subvert immunosurveillance.

As mentioned above, tumor-immune escape can occur through many different mechanisms, such as induction of an immunosuppressive state within the tumor microenvironment, up-regulation of resistance mechanisms, or re-
Coevolution of Leukemia and Host Immune Cells

duced immune recognition (Schreiber et al. 2011), each of which has been observed in CLL. Studies of gene-expression profiling of $\mathrm{CD}^{+}{ }^{+}$and $\mathrm{CD}^{+}{ }^{+} \mathrm{T}$ cells from CLL patients have revealed an expression signature of altered immune response, with changes in genes involved in cell differentiation, cytoskeleton formation, cell trafficking, and cytotoxicity. Consistent with these findings, defective immunological synapse formation with antigen-presenting cells (APCs) has been shown in CLL patients (Görgün et al. 2005; Ramsay et al. 2008, 2012). This cellular signaling structure orchestrates the complex communication between the $\mathrm{T}$ cell and the APC in a way that ensures detailed antigen recognition and effective $\mathrm{T}$ cell responses (Grakoui et al. 1999). In addition, $\mathrm{CD}^{+} \mathrm{T}$ cells from CLL patients express high levels of PD1, CTLA-4, CD160, and CD244, and show functional defects in proliferation and cytotoxicity (Motta et al. 2005; Gassner et al. 2012; Nunes et al. 2012; Riches et al. 2013). These findings are consistent with a phenotype of Tcell exhaustion, although CLL cells retain the ability to degranulate and produce protumor cytokines as opposed to classical exhaustion (Riches et al. 2013). Adding to this picture, $\mathrm{T}_{\text {reg-cell populations are elevated in CLL and }}$ MBL patients, and appear to play a major role in suppressing immune responses either by direct interaction with other immune cell types, such as effector Th17 cells or NK cells, or through immunosuppressive cytokines, such as IL-10 and transforming growth factor $\beta$ (TGF$\beta$ ) (Kitabayashi et al. 1995; Bluestone and Abbas 2003; Liu et al. 2006; Gowda et al. 2010; Costello et al. 2012; Jadidi-Niaragh et al. 2012).

Additional molecular mechanisms of evasion have been found to come from dysregulated NK-cell-mediated immune responses in CLL through (1) down-regulation of activating NKG2D receptors and corresponding ligands (Huergo-Zapico et al. 2014); (2) up-regulation of inhibitory killer cell immunoglobulin-like receptors (Junevik et al. 2007; Verheyden et al. 2009); (3) indirect suppression of NK activity exerted by $\mathrm{T}_{\text {reg }}$ cells (Gowda et al. 2010; Costello et al. 2012; Jadidi-Niaragh et al. 2012) and M2macrophages (Hasmim et al. 2015). Although 
little is known about the contribution of the monocyte-macrophage compartment to CLL development, constitutive M2 skewing was recently shown in CLL patients, based on high levels of interferon regulatory factor 4 (IRF4) transcription factor and low IL-12 levels, considered M2 and M1 markers, respectively (Audrito et al. 2015). Using the TCL1-tg mouse model, Hanna et al. likewise observed severe skewing of M2 macrophages, aberrantly high PD-L1 and PD-L2 expression, and secretion of multiple immunosuppressive cytokines, such as IL-10, TNF- $\alpha$, and CXCL9 by M2 macrophages, altogether likely contributing to T-cell exhaustion (Hanna et al. 2015). In addition to macrophages dysfunction, myeloid DCs from CLL patients are also severely defective, unable to effectively drive a Th1 response and display down-regulation of major histocompatibility complex class II (MHC-II) and up-regulation of PD-L1 (Orsini et al. 2003, 2004; Hanna et al. 2015). Another emerging population of suppressive cells, the so-called myeloid-derived suppressor cells (MDSCs), which are characterized as $\mathrm{CD}_{14}^{+}$cells lacking human leukocyte antigen-antigen-D-related (HLA-DR) expression $\left(\right.$ HLA-DR ${ }^{\text {lo }}$ ), have been found at increased absolute numbers in CLL patients, with higher levels of MDSCs correlated with disease progression and poorer prognosis (Jitschin et al. 2014; Liu et al. 2015). MDSCs suppressed in vitro $\mathrm{T}$-cell activation and proliferation and induced suppressive regulatory $\mathrm{CD}^{+} \mathrm{T}$ cells $\left(\mathrm{T}_{\text {reg }}\right)$ in CLL (Jitschin et al. 2014). Only a few studies have addressed the temporal changes in the quantitative and qualitative aspects of immunologic state of the normal immune cellular components in CLL patients with disease progression. Some investigators have examined the changes in absolute T- and NK-cell counts over time, with the consistent observations of increased counts in early-stage CLL patients as well as in patients with MBL compared to those with more a advanced disease (Palmer et al. 2008; Gonzalez-Rodriguez et al. 2010; Christopoulos et al. 2011; D’Arena et al. 2011b; Forconi and Moss 2015). Higher NK, $\mathrm{CD}^{+}$, and $\mathrm{CD} 4^{+}$ T-cell counts have been also consistently associated with better outcomes (Palmer et al. 2008;
Gonzalez-Rodriguez et al. 2010; Huergo-Zapico et al. 2014). Altogether, these observations suggest an initial expansion of T and NK cells, consistent with preserved antigen-presenting functions in early CLL cells. At the same time, higher levels of circulating Th17 cells and higher Th1:Th2 ratio have been observed in CLL compared with normal donors and both levels progressively decrease with disease progression (Van den Hove et al. 1998; Podhorecka et al. 2002; Jain et al. 2012; Hus et al. 2013; JadidiNiaragh et al. 2013; Sherry et al. 2015). Th1 and Th17 cells have been established as critically important cellular components in antitumor immunosurveillance in CLL (van Sandick et al. 2003; Fridman et al. 2012). An association between higher levels of circulating Th17 cell numbers and longer survival has been described (Jain et al. 2012; Jadidi-Niaragh et al. 2013; Sherry et al. 2015). In addition to Th1/Th2/ Th17 T-cell subsets, increased frequency in $\mathrm{T}_{\text {regs }}$ in CLL and MBL (Badoual et al. 2009), and correlation with disease progression and time to first treatment has been shown in CLL patients (Beyer et al. 2005; Giannopoulos et al. 2008; D’Arena et al. 2011a, 2012; Weiss et al. 2011; Lad et al. 2015). Finally, increased numbers of $\mathrm{T}_{\mathrm{FH}}$ cells have been consistently observed in CLL patients as compared to normal subjects, although their association with clinical stage has been controversial (Ahearne et al. 2013; Cha et al. 2013).

Higher levels of CTLA-4 and PD-1 have been consistently associated with rapidly progressive disease and worse outcome, supporting the notion of T-cell exhaustion as an immuneescape mechanism during CLL progression (Motta et al. 2005; Ramsay et al. 2008; Nunes et al. 2012; Brusa et al. 2013), even while the association between these features and clinical stage have not been strong (Gassner et al. 2012; Brusa et al. 2013; Grzywnowicz et al. 2015; Novák et al. 2015; Rusak et al. 2015). Recently, antibodies targeting the PD-1/PD-L1 interaction have shown impressive antitumor activity in solid and hematologic malignancies, highlighting the therapeutic opportunity for targeting the modulation of T-cell inhibitory molecules (Topalian et al. 2012; Armand et al. 2013; 
Ansell et al. 2015). This therapeutic direction for CLL is supported by recent work in CLL murine models showing that exposure to PD-L1-blocking antibodies prevented CLL development and reactivated immune effector functions (McClanahan et al. 2015a,b).

\section{GENERATION OF CLL-DIRECTED IMMUNE RESPONSES}

A key path for tumor control is through the mounting of an effective immune response against the tumor. Central to this endeavor is the ability of the immune system to recognize and drive responses against tumor antigens (Sensi and Anichini 2006).

In CLL, a limited spectrum of leukemia-associated antigens have been identified and tested. These have included fibromodulin, PRAME, MPP11, RHAMM/CD168 (Giannopoulos et al. 2006, 2010), and ROR1 (Hudecek et al. 2010). Prospective vaccination with RHAMM peptide has been tested in CLL patients, with responses limited to examination of patients in early disease (Giannopoulos et al. 2010). Notwithstanding, the identification of aberrantly expressed tumor-associated antigens (TAAs) has historically been time-consuming and laborious. Recent advances in mass spectrometry have facilitated the identification of a vast array of naturally presented HLA class I and class II binding peptides in primary CLL samples, and excite the possibility of expanding the spectrum of targetable entities (Kowalewski et al. 2015).

Until recently, the bulk of TAA discovery has relied on the identification of those targets with high expression in leukemia cells compared to normal cells. Recent advances, however, in NGS and peptide epitope prediction algorithms (Lin et al. 2008; Zhang et al. 2011; Cibulskis et al. 2013) have opened the possibility of systematically mining the genome for antigen epitopes, which are products of somatic mutations that generate protein-coding region changes, and predicting whether the resulting modified peptide sequences can potentially bind surface MHC class I molecules so that they can be recognized by the T-cell receptor (TCR) of cytotoxic T cells (Fig. 5) (Sensi and Anichini 2006; Ha- cohen et al. 2013). Indeed, application of this strategy to identify so-called tumor neoantigens has led to clinical evidence of natural and therapyinduced antitumor responses in mouse and human across solid tumors (Gubin et al. 2014; Yadav et al. 2014; Carreno et al. 2015; Rizvi et al. 2015; Schumacher and Schreiber 2015; Tran et al. 2015; Van Allen et al. 2015; Giannakis et al. 2016), as well as in CLL (Rajasagi et al. 2014).

A series of discoveries in solid tumors have described tumor escape mechanisms related to reduced immunogenicity of tumor cells. Loss of neoantigen expression has been described as one of these mechanisms, Rooney et al. reported increased cytolytic activity in tumors with higher neoantigen load and that depletion of neoantigen load was unexpectedly found in some tumor types, consistent with immunologic selective pressure (Rooney et al. 2015). Efficient processing of tumor epitopes by cellular proteolytic intermediates is essential for the generation of an effective antitumor cytotoxic response. Impaired antigen processing caused by deregulation of the proteasomal degradation has been consistently revealed as an immune escape mechanism in tumor cells (Sun et al. 2002; Guillaume et al. 2012; Ebstein et al. 2016). One of the most frequent causes of immune escape in human tumors is defects in the antigen-presenting machinery owing to HLA class I molecule down-regulation or loss (Restifo et al. 1993; Seliger et al. 2001, 2002; Paschen et al. 2006), low affinity peptide-MHC interactions (Engels et al. 2013), and, recently, a greater-than-expected frequency of somatic mutations in class I HLA genes, predicted to be loss of function, was discovered across cancers, associated with up-regulation of signatures of cytolytic activity characteristic of tumor infiltration by effector lymphocytes. This was especially pronounced in colorectal cancers (Shukla et al. 2015; Giannakis et al. 2016). The types of resistance mechanisms related to reduced immunogenicity developing in CLL remain to be seen.

\section{CONCLUSIONS AND FUTURE CHALLENGES}

Emerging evidence underscores the relevance of deciphering not only the genomic evolution of 
N. Purroy and C.J. Wu

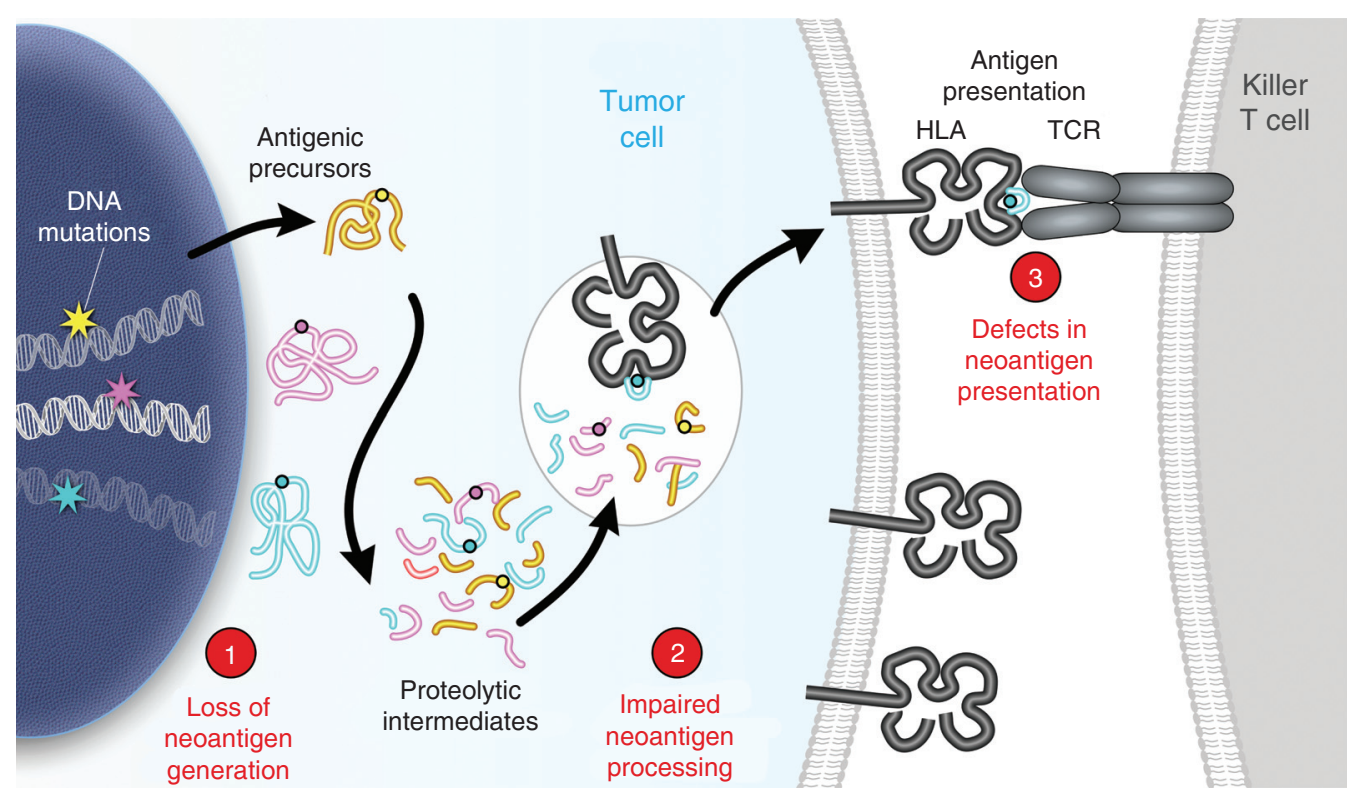

Figure 5. Somatic mutations have the potential to generate neoantigens. Neoantigens are produced as a result of somatic mutations in cancer cells. Major histocompatibility complex (MHC) class I molecules present processed epitopes on the tumor cell surface to effector T cells through the T-cell receptor (TCR). Several mechanisms of immune escape within this process are depicted: (1) loss of neoantigens generation, (2) impairment of antigen processing, and (3) defects in antigens presentation. HLA, Human leukocyte antigen.

tumor cells across time and therapies but also the temporal dissection of the immune composition that may govern these processes and, more importantly, the molecular interplay between both tumor and immune cells. A comprehensive understanding of the mechanisms that influences cancer immunoediting have suggested new immune-related prognostic markers and the biologic rationale for the growing classes of new immune-based cancer treatments, and offer the unique opportunity for refining personalized-based approaches to cancer treatment. Moreover, insights into the complexity of biological networks within the tumor microenvironment give us the chance to consider new mechanisms of treatment resistance that may inform us of new directions for clinical trials.

These concepts have important implications across cancer, including on CLL. In many ways, CLL presents a model system for dissecting out these concepts because of the ready accessibility of both malignant cells and surrounding immune cells, and because of its relatively indolent nature that enables interrogation of samples over time. We anticipate that new investigations in CLL will address critical questions in this area, including how do specific driver mutations affect the quality and quantity of tumor antigens? How does the burden of CLL neoantigens differ across the course of disease evolution? How does the genomic landscape of a tumor shape antitumor immune responses and how is the genomic landscape shaped by antitumor immune responses? How do driver mutations affect the antitumor immune response? What immune processes modulate CLL elimination and escape? Surely, with the advent of new and more sophisticated technologies and with our expanding understanding of cancer immunity, we can expect rapid progress in our understanding of this biology, with an impact on the development of personalized treatment approaches for this disease over the next few years.

\section{ACKNOWLEDGMENTS}

C.J.W. acknowledges support from the Blavatnik Family Foundation, National Heart, Lung, 
and Blood Institute (NHLBI) (1RO1HL10353201; 1RO1HL116452-01), and the National Cancer Institute (NCI) (1RO1CA155010-01A1; 1U10CA180861-01), and is a recipient of a Leukemia Lymphoma Translational Research Program Award. C.J.W. is a cofounder and scientific advisory board member of Neon Therapeutics.

\section{REFERENCES}

Ahearne MJ, Willimott S, Piñon L, Kennedy DB, Miall F, Dyer MJS, Wagner SD. 2013. Enhancement of CD154/ IL4 proliferation by the $\mathrm{T}$ follicular helper (Tfh) cytokine, IL21 and increased numbers of circulating cells resembling Tfh cells in chronic lymphocytic leukaemia. $\mathrm{Br} \mathrm{J}$ Haematol 162: 360-370.

Akira S, Takeda K. 2004. Toll-like receptor signalling. Nat Rev Immunol 4: 499-511.

Alexandrov LB, Nik-Zainal S, Wedge DC, Aparicio SAJR, Behjati S, Biankin AV, Bignell GR, Bolli N, Borg A, Børresen-Dale AL, et al. 2013. Signatures of mutational processes in human cancer. Nature 500: 415-421.

Ansell SM, Lesokhin AM, Borrello I, Halwani A, Scott EC, Gutierrez M, Schuster SJ, Millenson MM, Cattry D, Freeman GJ, et al. 2015. PD-1 blockade with nivolumab in relapsed or refractory Hodgkin's lymphoma. $N$ Engl J Med 372: 311-319.

Armand P, Nagler A, Weller EA, Devine SM, Avigan DE, Chen YB, Kaminski MS, Holland HK, Winter JN, Mason JR, et al. 2013. Disabling immune tolerance by programmed death-1 blockade with pidilizumab after autologous hematopoietic stem-cell transplantation for diffuse large B-cell lymphoma: Results of an international phase II trial. J Clin Oncol 31: 4199-4206.

Audrito V, Serra S, Brusa D, Mazzola F, Arruga F, Vaisitti T, Coscia M, Maffei R, Rossi D, Wang T, et al. 2015. Extracellular nicotinamide phosphoribosyltransferase (NAMPT) promotes M2 macrophage polarization in chronic lymphocytic leukemia. Blood 125: 111-123.

Badoual C, Hans S, Fridman WH, Brasnu D, Erdman S, Tartour E. 2009. Revisiting the prognostic value of regulatory T cells in patients with cancer. J Clin Oncol 27: e5e6; author reply e7.

Bagnara D, Kaufman MS, Calissano C, Marsilio S, Patten PEM, Simone R, Chum P, Yan XJ, Allen SL, Kolitz JE, et al. 2011. A novel adoptive transfer model of chronic lymphocytic leukemia suggests a key role for $\mathrm{T}$ lymphocytes in the disease. Blood 117: 5463-5472.

Beyer M, Kochanek M, Darabi K, Popov A, Jensen M, Endl E, Knolle PA, Thomas RK, von Bergwelt-Baildon M, Debey S, et al. 2005. Reduced frequencies and suppressive function of $\mathrm{CD} 4{ }^{+} \mathrm{CD} 25^{\text {hi }}$ regulatory $\mathrm{T}$ cells in patients with chronic lymphocytic leukemia after therapy with fludarabine. Blood 106: 2018-2025.

Bleul CC, Fuhlbrigge RC, Casasnovas JM, Aiuti A, Springer TA. 1996. A highly efficacious lymphocyte chemoattractant, stromal cell-derived factor 1 (SDF-1). J Exp Med 184: $1101-1109$.
Bluestone JA, Abbas AK. 2003. Natural versus adaptive regulatory T cells. Nat Rev Immunol 3: 253-257.

Brown JR, Byrd JC, Coutre SE, Benson DM, Flinn IW, Wagner-Johnston ND, Spurgeon SE, Kahl BS, Bello C, Webb HK, et al. 2014. Idelalisib, an inhibitor of phosphatidylinositol 3-kinase $\mathrm{p} 110 \delta$, for relapsed/refractory chronic lymphocytic leukemia. Blood 123: 3390-3397.

Brusa D, Serra S, Coscia M, Rossi D, D’Arena G, Laurenti L, Jaksic O, Fedele G, Inghirami G, Deaglio S, et al. 2013. The PD-1/PD-L1 axis contributes to T-cell dysfunction in chronic lymphocytic leukemia. Haematologica 98: 953-963.

Burger JA, Kipps TJ. 2002. Chemokine receptors and stromal cells in the homing and homeostasis of chronic lymphocytic leukemia B cells. Leuk Lymphoma 43: 461-466.

Burger JA, Burger M, Kipps TJ. 1999. Chronic lymphocytic leukemia B cells express functional CXCR4 chemokine receptors that mediate spontaneous migration beneath bone marrow stromal cells. Blood 94: 3658-3667.

Burger JA, Tsukada N, Burger M, Zvaifler NJ, Dell'Aquila M, Kipps TJ. 2000. Blood-derived nurse-like cells protect chronic lymphocytic leukemia B cells from spontaneous apoptosis through stromal cell-derived factor-1. Blood 96: $2655-2663$.

Burger JA, Quiroga MP, Hartmann E, Bürkle A, Wierda WG, Keating MJ, Rosenwald A. 2009. High-level expression of the T-cell chemokines CCL3 and CCL4 by chronic lymphocytic leukemia $B$ cells in nurselike cell cocultures and after BCR stimulation. Blood 113: 3050-3058.

Bürkle A, Niedermeier M, Schmitt-Gräff A, Wierda WG, Keating MJ, Burger JA. 2007. Overexpression of the CXCR5 chemokine receptor, and its ligand, CXCL13 in B-cell chronic lymphocytic leukemia. Blood 110: 33163325.

Buske C, Gogowski G, Schreiber K, Rave-Fränk M, Hiddemann W, Wörmann B. 1997. Stimulation of B-chronic lymphocytic leukemia cells by murine fibroblasts, IL-4, anti-CD40 antibodies, and the soluble CD40 ligand. Exp Hematol 25: 329-337.

Byrd JC, Furman RR, Coutre SE, Flinn IW, Burger JA, Blum KA, Grant B, Sharman JP, Coleman M, Wierda WG, et al. 2013. Targeting BTK with ibrutinib in relapsed chronic lymphocytic leukemia. $N$ Engl J Med 369: 32-42.

Byrd JC, Furman RR, Coutre SE, Burger JA, Blum KA, Coleman M, Wierda WG, Jones JA, Zhao W, Heerema NA, et al. 2015. Three-year follow-up of treatment-naïve and previously treated patients with CLL and SLL receiving single-agent ibrutinib. Blood 125: 2497-2506.

Cahill N, Rosenquist R. 2013. Uncovering the DNA methylome in chronic lymphocytic leukemia. Epigenetics 8: $138-148$.

Caligaris-Cappio F, Ghia P. 2008. Novel insights in chronic lymphocytic leukemia: Are we getting closer to understanding the pathogenesis of the disease? J Clin Oncol 26: 4497-4503.

Carreno BM, Magrini V, Becker-Hapak M, Kaabinejadian S, Hundal J, Petti AA, Ly A, Lie W-R, Hildebrand WH, Mardis ER, et al. 2015. Cancer immunotherapy. A dendritic cell vaccine increases the breadth and diversity of melanoma neoantigen-specific T cells. Science 348: $803-$ 808 . 
Cha Z, Zang Y, Guo H, Rechlic JR, Olasnova LM, Gu H, Tu X, Song H, Qian B. 2013. Association of peripheral CD4 ${ }^{+}$ CXCR5 $^{+} \mathrm{T}$ cells with chronic lymphocytic leukemia. Tumour Biol 34: 3579-3585.

Chilosi M, Pizzolo G, Caligaris-Cappio F, Ambrosetti A, Vinante F, Morittu L, Bonetti F, Fiore-Donati L, Janossy G. 1985. Immunohistochemical demonstration of follicular dendritic cells in bone marrow involvement of B-cell chronic lymphocytic leukemia. Cancer 56: 328-332.

Chiorazzi N, Rai KR, Ferrarini M. 2005. Chronic lymphocytic leukemia. N Engl J Med 352: 804-815.

Christopoulos P, Pfeifer D, Bartholomé K, Follo M, Timmer J, Fisch P, Veelken H. 2011. Definition and characterization of the systemic T-cell dysregulation in untreated indolent B-cell lymphoma and very early CLL. Blood 117: $3836-3846$

Chunsong H, Yuling H, Li W, Jie X, Gang Z, Qiuping Z, Qingping G, Kejian Z, Li Q, Chang AE, et al. 2006. CXC chemokine ligand 13 and CC chemokine ligand 19 cooperatively render resistance to apoptosis in $\mathrm{B}$ cell lineage acute and chronic lymphocytic leukemia $\mathrm{CD} 23^{+} \mathrm{CD}^{+} \mathrm{B}$ cells. J Immunol 177: 6713-6722.

Cibulskis K, Lawrence MS, Carter SL, Sivachenko A, Jaffe D, Sougnez C, Gabriel S, Meyerson M, Lander ES, Getz G. 2013. Sensitive detection of somatic point mutations in impure and heterogeneous cancer samples. Nat Biotechnol 31: 213-219.

Cols M, Barra CM, He B, Puga I, Xu W, Chiu A, Tam W, Knowles DM, Dillon SR, Leonard JP, et al. 2012. Stromal endothelial cells establish a bidirectional crosstalk with chronic lymphocytic leukemia cells through the TNFrelated factors BAFF, APRIL, and CD40L. J Immunol 188: $6071-6083$.

Costello RT, Knoblauch B, Sanchez C, Mercier D, Le Treut T, Sébahoun G. 2012. Expression of natural killer cell activating receptors in patients with chronic lymphocytic leukaemia. Immunology 135: 151-157.

Damle RN, Wasil T, Fais F, Ghiotto F, Valetto A, Allen SL, Buchbinder A, Budman D, Dittmar K, Kolitz J, et al. 1999. Ig V gene mutation status and CD38 expression as novel prognostic indicators in chronic lymphocytic leukemia. Blood 94: 1840-1847.

D’Arena G, Laurenti L, Minervini MM, Deaglio S, Bonello L, De Martino L, De Padua L, Savino L, Tarnani M, De Feo V, et al. 2011a. Regulatory T-cell number is increased in chronic lymphocytic leukemia patients and correlates with progressive disease. Leuk Res 35: 363-368.

D’Arena G, Rossi G, Minervini MM, Savino L, D'Auria F, Laurenti L, Del Principe MI, Deaglio S, Biagi A, De Martino L, et al. 2011b. Circulating regulatory T cells in "clinical" monoclonal B-cell lymphocytosis. Int J Immunopathol Pharmacol 24: 915-923.

D’Arena G, D'Auria F, Simeon V, Laurenti L, Deaglio S, Mansueto G, Del Principe MI, Statuto T, Pietrantuono G, Guariglia R, et al. 2012. A shorter time to the first treatment may be predicted by the absolute number of regulatory T-cells in patients with Rai stage 0 chronic lymphocytic leukemia. Am J Hematol 87: 628-631.

Deaglio S, Aydin S, Grand MM, Vaisitti T, Bergui L, D’Arena G, Chiorino G, Malavasi F. 2010. CD38/CD31 interactions activate genetic pathways leading to proliferation and migration in chronic lymphocytic leukemia cells. Mol Med 16: 87-91.

Döhner H, Stilgenbauer S, Benner A, Leupolt E, Kröber A, Bullinger L, Döhner K, Bentz M, Lichter P. 2000. Genomic aberrations and survival in chronic lymphocytic leukemia. N Engl J Med 343: 1910-1916.

Dühren-von Minden M, Übelhart R, Schneider D, Wossning T, Bach MP, Buchner M, Hofmann D, Surova E, Follo M, Köhler F, et al. 2012. Chronic lymphocytic leukaemia is driven by antigen-independent cell-autonomous signalling. Nature 489: 309-312.

Dunn GP, Bruce AT, Ikeda H, Old LJ, Schreiber RD. 2002. Cancer immunoediting: From immunosurveillance to tumor escape. Nat Immunol 3: 991-998.

Dunn GP, Old LJ, Schreiber RD. 2004. The three Es of cancer immunoediting. Annu Rev Immunol 22: 329-360.

Ebstein F, Keller M, Paschen A, Walden P, Seeger M, Bürger E, Krüger E, Schadendorf D, Kloetzel P-M, Seifert U. 2016. Exposure to Melan-A/MART-126-35 tumor epitope specific $\mathrm{CD}^{+} \mathrm{T}$ cells reveals immune escape by affecting the ubiquitin-proteasome system (UPS). Sci Rep 6: 25208.

Engels B, Engelhard VH, Sidney J, Sette A, Binder DC, Liu RB, Kranz DM, Meredith SC, Rowley DA, Schreiber H. 2013. Relapse or eradication of cancer is predicted by peptide-major histocompatibility complex affinity. Cancer Cell 23: 516-526.

Fabbri G, Rasi S, Rossi D, Trifonov V, Khiabanian H, Ma J, Grunn A, Fangazio M, Capello D, Monti S, et al. 2011. Analysis of the chronic lymphocytic leukemia coding genome: Role of NOTCH1 mutational activation. J Exp Med 208: 1389-1401.

Fais F, Ghiotto F, Hashimoto S, Sellars B, Valetto A, Allen SL, Schulman P, Vinciguerra VP, Rai K, Rassenti LZ, et al. 1998. Chronic lymphocytic leukemia B cells express restricted sets of mutated and unmutated antigen receptors. J Clin Invest 102: 1515-1525.

Ferradini L, Mackensen A, Genevée C, Bosq J, Duvillard P, Avril MF, Hercend T. 1993. Analysis of T cell receptor variability in tumor-infiltrating lymphocytes from a human regressive melanoma. Evidence for in situ T cell clonal expansion. J Clin Invest 91: 1183-1190.

Forconi F, Moss P. 2015. Perturbation of the normal immune system in patients with CLL. Blood 126: 573-581.

Fridman WH, Pagès F, Sautès-Fridman C, Galon J. 2012. The immune contexture in human tumours: Impact on clinical outcome. Nat Rev Cancer 12: 298-306.

Furman RR, Sharman JP, Coutre SE, Cheson BD, Pagel JM, Hillmen P, Barrientos JC, Zelenetz AD, Kipps TJ, Flinn I, et al. 2014. Idelalisib and rituximab in relapsed chronic lymphocytic leukemia. N Engl J Med 370: 997-1007.

Gassner FJ, Zaborsky N, Neureiter D, Huemer M, Egle A, Hartmann TN, Greil R, Geisberger R. 2012. T cell exhaustion contributes to immune evasion in chronic lymphocytic leukaemia. ASH Annu Meet Abstr 120: 1773.

Ghia P, Strola G, Granziero L, Geuna M, Guida G, Sallusto F, Ruffing N, Montagna L, Piccoli P, Chilosi M, et al. 2002. Chronic lymphocytic leukemia B cells are endowed with the capacity to attract $\mathrm{CD} 4^{+}, \mathrm{CD} 40 \mathrm{~L}^{+} \mathrm{T}$ cells by producing CCL22. Eur J Immunol 32: 1403-1413. 
Giannopoulos K, Li L, Bojarska-Junak A, Rolinski J, Dmoszynska A, Hus I, Greiner J, Renner C, Döhner H, Schmitt M. 2006. Expression of RHAMM/CD168 and other tumor-associated antigens in patients with B-cell chronic lymphocytic leukemia. Int J Oncol 29: 95-103.

Giannopoulos K, Schmitt M, Kowal M, Wlasiuk P, BojarskaJunak A, Chen J, Rolinski J, Dmoszynska A. 2008. Characterization of regulatory $\mathrm{T}$ cells in patients with B-cell chronic lymphocytic leukemia. Oncol Rep 20: 677-682.

Giannopoulos K, Dmoszynska A, Kowal M, Rolinski J, Gostick E, Price DA, Greiner J, Rojewski M, Stilgenbauer S, Döhner H, et al. 2010. Peptide vaccination elicits leukemia-associated antigen-specific cytotoxic $\mathrm{CD} 8^{+} \mathrm{T}$-cell responses in patients with chronic lymphocytic leukemia. Leukemia 24: 798-805.

Giannakis M, Mu XJ, Shukla SA, Qian ZR, Cohen O, Nishihara R, Bahl S, Cao Y, Amin-Mansour A, Yamauchi M, et al. 2016. Genomic correlates of immune-cell infiltrates in colorectal carcinoma. Cell Rep 15: 857-865.

Girardi M, Oppenheim DE, Steele CR, Lewis JM, Glusac E, Filler R, Hobby P, Sutton B, Tigelaar RE, Hayday AC. 2001. Regulation of cutaneous malignancy by $\gamma \delta \mathrm{T}$ cells. Science 294: 605-609.

Gonzalez-Rodriguez AP, Contesti J, Huergo-Zapico L, Lopez-Soto A, Fernández-Guizán A, Acebes-Huerta A, Gonzalez-Huerta AJ, Gonzalez E, Fernandez-Alvarez C, Gonzalez S. 2010. Prognostic significance of CD8 and CD4 T cells in chronic lymphocytic leukemia. Leuk Lymphoma 51: 1829-1836.

Görgün G, Holderried TAW, Zahrieh D, Neuberg D, Gribben JG. 2005. Chronic lymphocytic leukemia cells induce changes in gene expression of CD4 and CD8 T cells. $J$ Clin Invest 115: 1797-1805.

Gowda A, Ramanunni A, Cheney C, Rozewski D, Kindsvogel W, Lehman A, Jarjoura D, Caligiuri M, Byrd JC, Muthusamy N. 2010. Differential effects of IL-2 and IL-21 on expansion of the $\mathrm{CD} 4{ }^{+} \mathrm{CD} 25^{+} \mathrm{Foxp}^{+}{ }^{+}$Tregulatory cells with redundant roles in natural killer cell mediated antibody dependent cellular cytotoxicity in chronic lymphocytic leukemia. MAbs 2: 35-41.

Grakoui A, Bromley SK, Sumen C, Davis MM, Shaw AS, Allen PM, Dustin ML. 1999. The immunological synapse: A molecular machine controlling $\mathrm{T}$ cell activation. Science 285: 221-227.

Granziero L, Ghia P, Circosta P, Gottardi D, Strola G, Geuna M, Montagna L, Piccoli P, Chilosi M, Caligaris-Cappio F. 2001. Survivin is expressed on CD40 stimulation and interfaces proliferation and apoptosis in B-cell chronic lymphocytic leukemia. Blood 97: 2777-2783.

Greaves M, Maley CC. 2012. Clonal evolution in cancer. Nature 481: 306-313.

Grzywnowicz M, Karczmarczyk A, Skorka K, Zajac M, Zaleska J, Chocholska S, Tomczak W, Giannopoulos K. 2015. Expression of programmed death 1 ligand in different compartments of chronic lymphocytic leukemia. Acta Haematol 134: 255-262.

Gubin MM, Zhang X, Schuster H, Caron E, Ward JP, Noguchi T, Ivanova Y, Hundal J, Arthur CD, Krebber WJ, et al. 2014. Checkpoint blockade cancer immunotherapy targets tumour-specific mutant antigens. Nature 515: 577 581.
Guièze R, Wu CJ. 2015. Genomic and epigenomic heterogeneity in chronic lymphocytic leukemia. Blood 126: $445-453$.

Guillaume B, Stroobant V, Bousquet-Dubouch M-P, Colau D, Chapiro J, Parmentier N, Dalet A, Van den Eynde BJ. 2012. Analysis of the processing of seven human tumor antigens by intermediate proteasomes. J Immunol 189: 3538-3547.

Hacohen N, Fritsch EF, Carter TA, Lander ES, Wu CJ. 2013. Getting personal with neoantigen-based therapeutic cancer vaccines. Cancer Immunol Res 1: 11-15.

Hamblin TJ, Davis Z, Gardiner A, Oscier DG, Stevenson FK. 1999. Unmutated Ig $V_{H}$ genes are associated with a more aggressive form of chronic lymphocytic leukemia. Blood 94: $1848-1854$.

Hanahan D, Weinberg RA. 2000. The hallmarks of cancer. Cell 100: $57-70$.

Hanna BS, McClanahan F, Yazdanparast H, Zaborsky N, Kalter V, Rößner PM, Benner A, Dürr C, Egle A, Gribben JG, et al. 2015. Depletion of CLL-associated patrolling monocytes and macrophages controls disease development and repairs immune dysfunction in vivo. Leukemia 30: $570-579$.

Hasmim M, Messai Y, Ziani L, Thiery J, Bouhris JH, Noman MZ, Chouaib S. 2015. Critical role of tumor microenvironment in shaping NK cell functions: Implication of hypoxic stress. Front Immunol 6: 482.

Heinig K, Gätjen M, Grau M, Stache V, Anagnostopoulos I, Gerlach K, Niesner RA, Cseresnyes Z, Hauser AE, Lenz P, et al. 2014. Access to follicular dendritic cells is a pivotal step in murine chronic lymphocytic leukemia B-cell activation and proliferation. Cancer Discov 4: 1448-1465.

Herman SEM, Barr PM, McAuley EM, Liu D, Wiestner A, Friedberg JW. 2013. Fostamatinib inhibits B-cell receptor signaling, cellular activation and tumor proliferation in patients with relapsed and refractory chronic lymphocytic leukemia. Leukemia 27: 1769-1773.

Hudecek M, Schmitt TM, Baskar S, Lupo-Stanghellini MT, Nishida T, Yamamoto TN, Bleakley M, Turtle CJ, Chang WC, Greisman HA, et al. 2010. The B-cell tumor-associated antigen ROR1 can be targeted with $\mathrm{T}$ cells modified to express a ROR1-specific chimeric antigen receptor. Blood 116: 4532-4541.

Huergo-Zapico L, Acebes-Huerta A, Gonzalez-Rodriguez AP, Contesti J, Gonzalez-García E, Payer AR, Villa-Alvarez M, Fernández-Guizán A, López-Soto A, Gonzalez S. 2014. Expansion of NK cells and reduction of NKG2D expression in chronic lymphocytic leukemia. Correlation with progressive disease. PloS ONE 9: e108326.

Hus I, Bojarska-Junak A, Chocholska S, Tomczak W, Woś J, Dmoszyńska A, Roliński J. 2013. Th17/IL-17A might play a protective role in chronic lymphocytic leukemia immunity. PloS ONE 8: e78091.

Jadidi-Niaragh F, Jeddi-Tehrani M, Ansaripour B, Razavi SM, Sharifian RA, Shokri F. 2012. Reduced frequency of NKT-like cells in patients with progressive chronic lymphocytic leukemia. Med Oncol 29: 3561-3569.

Jadidi-Niaragh F, Ghalamfarsa G, Memarian A, AsgarianOmran H, Razavi SM, Sarrafnejad A, Shokri F. 2013. Downregulation of IL-17-producing T cells is associated with regulatory $\mathrm{T}$ cell expansion and disease progression 
in chronic lymphocytic leukemia. Tumour Biol 34: 929940.

Jain P, Javdan M, Feger FK, Chiu PY, Sison C, Damle RN, Bhuiya TA, Sen F, Abruzzo LV, Burger JA, et al. 2012. Th17 and non-Th17 interleukin-17-expressing cells in chronic lymphocytic leukemia: Delineation, distribution, and clinical relevance. Haematologica 97: 599-607.

Jia L, Clear A, Liu FT, Matthews J, Uddin N, McCarthy A, Hoxha E, Durance C, Iqbal S, Gribben JG. 2014. Extracellular HMGB1 promotes differentiation of nurse-like cells in chronic lymphocytic leukemia. Blood 123: 1709_ 1719.

Jitschin R, Braun M, Büttner M, Dettmer-Wilde K, Bricks J, Berger J, Eckart MJ, Krause SW, Oefner PJ, Le Blanc K, et al. 2014. CLL-cells induce IDO ${ }^{\text {hi }}$ CD1 $4^{+} \mathrm{HLA}^{-D R^{\mathrm{lo}}}$ myeloid-derived suppressor cells that inhibit T-cell responses and promote $\mathrm{T}_{\text {Regs. }}$ Blood 124: 750-760.

Junevik K, Werlenius O, Hasselblom S, Jacobsson S, Nilsson-Ehle H, Andersson PO. 2007. The expression of NK cell inhibitory receptors on cytotoxic $\mathrm{T}$ cells in B-cell chronic lymphocytic leukaemia (B-CLL). Ann Hematol 86: 89-94.

Kitabayashi A, Hirokawa M, Miura AB. 1995. The role of interleukin-10 (IL-10) in chronic B-lymphocytic leukemia: IL-10 prevents leukemic cells from apoptotic cell death. Int J Hematol 62: 99-106.

Klein U, Dalla-Favera R. 2008. Germinal centres: Role in Bcell physiology and malignancy. Nat Rev Immunol 8: 22 33.

Klein U, Lia M, Crespo M, Siegel R, Shen Q, Mo T, AmbesiImpiombato A, Califano A, Migliazza A, Bhagat G, et al 2010. The DLEU2/miR-15a/16-1 cluster controls B cell proliferation and its deletion leads to chronic lymphocytic leukemia. Cancer Cell 17: 28-40.

Koebel CM, Vermi W, Swann JB, Zerafa N, Rodig SJ, Old LJ, Smyth MJ, Schreiber RD. 2007. Adaptive immunity maintains occult cancer in an equilibrium state. Nature 450: 903-907.

Kowalewski DJ, Schuster H, Backert L, Berlin C, Kahn S, Kanz L, Salih HR, Rammensee H-G, Stevanovic S, Stickel JS. 2015. HLA ligandome analysis identifies the underlying specificities of spontaneous antileukemia immune responses in chronic lymphocytic leukemia (CLL). Proc Natl Acad Sci 112: E166-E175.

Kroemer G, Senovilla L, Galluzzi L, André F, Zitvogel L. 2015. Natural and therapy-induced immunosurveillance in breast cancer. Nat Med 21: 1128-1138.

Kulis M, Heath S, Bibikova M, Queirós AC, Navarro A, Clot G, Martínez-Trillos A, Castellano G, Brun-Heath I, Pinyol M, et al. 2012. Epigenomic analysis detects widespread gene-body DNA hypomethylation in chronic lymphocytic leukemia. Nat Genet 44: 1236-1242.

Lad DP, Varma S, Varma N, Sachdeva MUS, Bose P, Malhotra P. 2015. Regulatory T-cell and T-helper 17 balance in chronic lymphocytic leukemia progression and autoimmune cytopenias. Leuk Lymphoma 56: 2424-2428.

Landau DA, Carter SL, Stojanov P, McKenna A, Stevenson K, Lawrence MS, Sougnez C, Stewart C, Sivachenko A, Wang L, et al. 2013. Evolution and impact of subclonal mutations in chronic lymphocytic leukemia. Cell 152: 714-726.
Landau DA, Clement K, Ziller MJ, Boyle P, Fan J, Gu H, Stevenson K, Sougnez C, Wang L, Li S, et al. 2014. Locally disordered methylation forms the basis of intratumor methylome variation in chronic lymphocytic leukemia. Cancer Cell 26: 813-825.

Landau DA, Tausch E, Taylor-Weiner AN, Stewart C, Reiter JG, Bahlo J, Kluth S, Bozic I, Lawrence M, Böttcher S, et al. 2015. Mutations driving CLL and their evolution in progression and relapse. Nature 526: 525-530.

Landgren O, Albitar M, Ma W, Abbasi F, Hayes RB, Ghia P, Marti GE, Caporaso NE. 2009. B-cell clones as early markers for chronic lymphocytic leukemia. $N$ Engl $J$ Med 360: 659-667.

Lawrence MS, Stojanov P, Polak P, Kryukov GV, Cibulskis K, Sivachenko A, Carter SL, Stewart C, Mermel CH, Roberts SA, et al. 2013. Mutational heterogeneity in cancer and the search for new cancer-associated genes. Nature 499: 214-218.

Lawrence MS, Stojanov P, Mermel CH, Robinson JT, Garraway LA, Golub TR, Meyerson M, Gabriel SB, Lander ES, Getz G. 2014. Discovery and saturation analysis of cancer genes across 21 tumour types. Nature 505: $495-$ 501.

Lin HH, Ray S, Tongchusak S, Reinherz EL, Brusic V. 2008. Evaluation of MHC class I peptide binding prediction servers: Applications for vaccine research. BMC Immunol 9: 8 .

Lion E, Willemen Y, Berneman ZN, Van Tendeloo VFI, Smits ELJ. 2012. Natural killer cell immune escape in acute myeloid leukemia. Leukemia 26: 2019-2026.

Liu YJ, Grouard G, de Bouteiller O, Banchereau J. 1996. Follicular dendritic cells and germinal centers. Int Rev Cytol 166: 139-179.

Liu W, Putnam AL, Xu-Yu Z, Szot GL, Lee MR, Zhu S, Gottlieb PA, Kapranov P, Gingeras TR, Fazekas de St Groth B, et al. 2006. CD127 expression inversely correlates with FoxP3 and suppressive function of human CD4 $+\mathrm{T}_{\text {reg }}$ cells. J Exp Med 203: 1701-1711.

Liu J, Zhou Y, Huang Q, Qiu L. 2015. CD14 ${ }^{+}$HLA-DR ${ }^{\text {low } /-}$ expression: A novel prognostic factor in chronic lymphocytic leukemia. Oncol Lett 9: 1167-1172.

Maffei R, Bulgarelli J, Fiorcari S, Bertoncelli L, Martinelli S, Guarnotta C, Castelli I, Deaglio S, Debbia G, De Biasi S, et al. 2013. The monocytic population in chronic lymphocytic leukemia shows altered composition and deregulation of genes involved in phagocytosis and inflammation. Haematologica 98: 1115-1123.

Martincorena I, Roshan A, Gerstung M, Ellis P, Van Loo P, McLaren S, Wedge DC, Fullam A, Alexandrov LB, Tubio JM, et al. 2015. Tumor evolution. High burden and pervasive positive selection of somatic mutations in normal human skin. Science 348: 880-886.

Martínez-Trillos A, Pinyol M, Navarro A, Aymerich M, Jares P, Juan M, Rozman M, Colomer D, Delgado J, Giné E, et al. 2014. Mutations in TLR/MYD88 pathway identify a subset of young chronic lymphocytic leukemia patients with favorable outcome. Blood 123: 3790-3796.

Marusyk A, Tabassum DP, Altrock PM, Almendro V, Michor F, Polyak K. 2014. Non-cell-autonomous driving of tumour growth supports sub-clonal heterogeneity. Nature 514: 54-58. 
McClanahan F, Hanna B, Miller S, Clear AJ, Lichter P, Gribben JG, Seiffert M. 2015a. PD-L1 checkpoint blockade prevents immune dysfunction and leukemia development in a mouse model of chronic lymphocytic leukemia. Blood 126: 203-211.

McClanahan F, Riches JC, Miller S, Day WP, Kotsiou E, Neuberg D, Croce CM, Capasso M, Gribben JG. 2015b. Mechanisms of PD-L1/PD-1-mediated CD8 T-cell dysfunction in the context of aging-related immune defects in the E $\mu$-TCL1 CLL mouse model. Blood 126: 212-221.

Mittal D, Gubin MM, Schreiber RD, Smyth MJ. 2014. New insights into cancer immunoediting and its three component phases-Elimination, equilibrium and escape. Curr Opin Immunol 27: 16-25.

Möhle R, Failenschmid C, Bautz F, Kanz L. 1999. Overexpression of the chemokine receptor CXCR4 in B cell chronic lymphocytic leukemia is associated with increased functional response to stromal cell-derived factor-1 (SDF-1). Leukemia 13: 1954-1959.

Motta M, Rassenti L, Shelvin BJ, Lerner S, Kipps TJ, Keating MJ, Wierda WG. 2005. Increased expression of CD152 (CTLA-4) by normal $\mathrm{T}$ lymphocytes in untreated patients with B-cell chronic lymphocytic leukemia. Leukemia 19: 1788-1793.

Müller-Hermelink N, Braumüller H, Pichler B, Wieder T, Mailhammer R, Schaak K, Ghoreschi K, Yazdi A, Haubner R, Sander CA, et al. 2008. TNFR1 signaling and IFN$\gamma$ signaling determine whether $\mathrm{T}$ cells induce tumor dormancy or promote multistage carcinogenesis. Cancer Cell 13: $507-518$.

Ngiow SF, Teng MWL, Smyth MJ. 2013. A balance of interleukin-12 and -23 in cancer. Trends Immunol 34: 548555.

Ngo VN, Young RM, Schmitz R, Jhavar S, Xiao W, Lim KH, Kohlhammer H, Xu W, Yang Y, Zhao H, et al. 2011. Oncogenically active MYD88 mutations in human lymphoma. Nature 470: 115-119.

Nishio M, Endo T, Tsukada N, Ohata J, Kitada S, Reed JC, Zvaifler NJ, Kipps TJ. 2005. Nurselike cells express BAFF and APRIL, which can promote survival of chronic lymphocytic leukemia cells via a paracrine pathway distinct from that of SDF-1 $\alpha$. Blood 106: 1012-1020.

Novák M, Procházka V, Turcsányi P, Papajík T. 2015. Numbers of $\mathrm{CD} 8^{+} \mathrm{PD}-1^{+}$and $\mathrm{CD} 4^{+} \mathrm{PD}-1^{+}$cells in peripheral blood of patients with chronic lymphocytic leukemia are independent of binet stage and are significantly higher compared to healthy volunteers. Acta Haematol 134: $208-214$.

Nunes C, Wong R, Mason M, Fegan C, Man S, Pepper C. 2012. Expansion of a $\mathrm{CD} 8^{+} \mathrm{PD}-1^{+}$replicative senescence phenotype in early stage CLL patients is associated with inverted CD4:CD8 ratios and disease progression. Clin Cancer Res 18: 678-687.

Oakes CC, Claus R, Gu L, Assenov Y, Hüllein J, Zucknick M, Bieg M, Brocks D, Bogatyrova O, Schmidt CR, et al. 2014. Evolution of DNA methylation is linked to genetic aberrations in chronic lymphocytic leukemia. Cancer Discov 4: $348-361$.

Oakes CC, Seifert M, Assenov Y, Gu L, Przekopowitz M, Ruppert AS, Wang Q, Imbusch CD, Serva A, Koser SD, et al. 2016. DNA methylation dynamics during B cell maturation underlie a continuum of disease phenotypes
Coevolution of Leukemia and Host Immune Cells

in chronic lymphocytic leukemia. Nat Genet 48: 253264.

O'Brien S, Furman RR, Coutre SE, Sharman JP, Burger JA, Blum KA, Grant B, Richards DA, Coleman M, Wierda WG, et al. 2014. Ibrutinib as initial therapy for elderly patients with chronic lymphocytic leukaemia or small lymphocytic lymphoma: An open-label, multicentre, phase 1b/2 trial. Lancet Oncol 15: 48-58.

Orsini E, Guarini A, Chiaretti S, Mauro FR, Foa R. 2003. The circulating dendritic cell compartment in patients with chronic lymphocytic leukemia is severely defective and unable to stimulate an effective T-cell response. Cancer Res 63: 4497-4506.

Orsini E, Pasquale A, Maggio R, Calabrese E, Mauro FR, Giammartini E, Guarini A, Foa R. 2004. Phenotypic and functional characterization of monocyte-derived dendritic cells in chronic lymphocytic leukaemia patients: Influence of neoplastic CD19 cells in vivo and in vitro. Br J Haematol 125: 720-728.

Os A, Bürgler S, Ribes AP, Funderud A, Wang D, Thompson KM, Tjønnfjord GE, Bogen B, Munthe LA. 2013. Chronic lymphocytic leukemia cells are activated and proliferate in response to specific T helper cells. Cell Rep 4: 566-577.

Oscier DG, Thompsett A, Zhu D, Stevenson FK. 1997. Differential rates of somatic hypermutation in $\mathrm{V}_{\mathrm{H}}$ genes among subsets of chronic lymphocytic leukemia defined by chromosomal abnormalities. Blood 89: 4153-4160.

Palmer S, Hanson CA, Zent CS, Porrata LF, Laplant B, Geyer SM, Markovic SN, Call TG, Bowen DA, Jelinek DF, et al. 2008. Prognostic importance of T and NK-cells in a consecutive series of newly diagnosed patients with chronic lymphocytic leukaemia. Br J Haematol 141: 607-614.

Pardoll DM. 2012. The blockade of immune checkpoints in cancer immunotherapy. Nat Rev Cancer 12: 252-264.

Paschen A, Arens N, Sucker A, Greulich-Bode KM, Fonsatti E, Gloghini A, Striegel S, Schwinn N, Carbone A, Hildenbrand R, et al. 2006. The coincidence of chromosome 15 aberrations and $\beta 2$-microglobulin gene mutations is causative for the total loss of human leukocyte antigen class I expression in melanoma. Clin Cancer Res 12: 3297-3305.

Patten PEM, Buggins AGS, Richards J, Wotherspoon A, Salisbury J, Mufti GJ, Hamblin TJ, Devereux S. 2008. CD38 expression in chronic lymphocytic leukemia is regulated by the tumor microenvironment. Blood 111: 5173-5181.

Pedersen IM, Kitada S, Leoni LM, Zapata JM, Karras JG, Tsukada N, Kipps TJ, Choi YS, Bennett F, Reed JC. 2002. Protection of CLL B cells by a follicular dendritic cell line is dependent on induction of Mcl-1. Blood 100: 17951801.

Pei L, Choi J-H, Liu J, Lee E-J, McCarthy B, Wilson JM, Speir E, Awan F, Tae H, Arthur G, et al. 2012. Genome-wide DNA methylation analysis reveals novel epigenetic changes in chronic lymphocytic leukemia. Epigenetics 7: 567-578.

Pleasance ED, Cheetham RK, Stephens PJ, McBride DJ, Humphray SJ, Greenman CD, Varela I, Lin M-L, Ordóñez GR, Bignell GR, et al. 2010. A comprehensive catalogue of somatic mutations from a human cancer genome. Nature 463: 191-196. 
Podhorecka M, Dmoszynska A, Rolinski J, Wasik E. 2002. T type 1/type 2 subsets balance in B-cell chronic lymphocytic leukemia-The three-color flow cytometry analysis. Leuk Res 26: 657-660.

Porter DL, Hwang W-T, Frey NV, Lacey SF, Shaw PA, Loren AW, Bagg A, Marcucci KT, Shen A, Gonzalez V, et al. 2015. Chimeric antigen receptor $\mathrm{T}$ cells persist and induce sustained remissions in relapsed refractory chronic lymphocytic leukemia. Sci Transl Med 7: 303ra139.

Puente XS, Pinyol M, Quesada V, Conde L, Ordóñez GR, Villamor N, Escaramis G, Jares P, Beà S, González-Díaz $\mathrm{M}$, et al. 2011. Whole-genome sequencing identifies recurrent mutations in chronic lymphocytic leukaemia. Nature 475: 101-105.

Puente XS, Beà S, Valdés-Mas R, Villamor N, GutiérrezAbril J, Martín-Subero JI, Munar M, Rubio-Pérez C, Jares P, Aymerich M, et al. 2015. Non-coding recurrent mutations in chronic lymphocytic leukaemia. Nature 526: 519-524.

Queirós AC, Villamor N, Clot G, Martinez-Trillos A, Kulis M, Navarro A, Penas EMM, Jayne S, Majid A, Richter J, et al. 2015. A B-cell epigenetic signature defines three biologic subgroups of chronic lymphocytic leukemia with clinical impact. Leukemia 29: 598-605.

Quesada V, Conde L, Villamor N, Ordóñez GR, Jares P, Bassaganyas L, Ramsay AJ, Beà S, Pinyol M, MartínezTrillos A, et al. 2012. Exome sequencing identifies recurrent mutations of the splicing factor SF3B1 gene in chronic lymphocytic leukemia. Nat Genet 44: 47-52.

Rajasagi M, Shukla SA, Fritsch EF, Keskin DB, DeLuca D, Carmona E, Zhang W, Sougnez C, Cibulskis K, Sidney J, et al. 2014. Systematic identification of personal tumorspecific neoantigens in chronic lymphocytic leukemia. Blood 124: 453-462.

Ramsay AG, Johnson AJ, Lee AM, Gorgün G, Le Dieu R, Blum W, Byrd JC, Gribben JG. 2008. Chronic lymphocytic leukemia $\mathrm{T}$ cells show impaired immunological synapse formation that can be reversed with an immunomodulating drug. J Clin Invest 118: 2427-2437.

Ramsay AG, Clear AJ, Fatah R, Gribben JG. 2012. Multiple inhibitory ligands induce impaired T-cell immunologic synapse function in chronic lymphocytic leukemia that can be blocked with lenalidomide: Establishing a reversible immune evasion mechanism in human cancer. Blood 120: $1412-1421$

Restifo NP, Esquivel F, Kawakami Y, Yewdell JW, Mulé JJ, Rosenberg SA, Bennink JR. 1993. Identification of human cancers deficient in antigen processing. J Exp Med 177: $265-272$.

Riches JC, Davies JK, McClanahan F, Fatah R, Iqbal S, Agrawal S, Ramsay AG, Gribben JG. 2013. T cells from CLL patients exhibit features of T-cell exhaustion but retain capacity for cytokine production. Blood 121: $1612-1621$.

Rizvi NA, Hellmann MD, Snyder A, Kvistborg P, Makarov V, Havel JJ, Lee W, Yuan J, Wong P, Ho TS, et al. 2015. Cancer immunology. Mutational landscape determines sensitivity to PD-1 blockade in non-small cell lung cancer. Science 348: 124-128.

Rooney MS, Shukla SA, Wu CJ, Getz G, Hacohen N. 2015. Molecular and genetic properties of tumors associated with local immune cytolytic activity. Cell 160: 48-61.
Rusak M, Eljaszewicz A, Bołkun Ł, Łuksza E, Łapuć I, Piszcz J, Singh P, Dąbrowska M, Bodzenta-Łukaszyk A, Kłoczko J, et al. 2015. Prognostic significance of PD-1 expression on peripheral blood $\mathrm{CD} 4^{+} \mathrm{T}$ cells in patients with newly diagnosed chronic lymphocytic leukemia. Pol Arch Med Wewn 125: 553-559.

Sachanas S, Levidou G, Angelopoulou MK, Moschogiannis M, Yiakoumis X, Kalpadakis C, Vassilakopoulos TP, Kontopidou F, Tsirkinidis P, Dimitrakopoulou A, et al. 2013. Apoptotic and proliferative characteristics of proliferation centers in lymph node sections of patients with chronic lymphocytic leukemia. Leuk Lymphoma 55: 571-582.

Savitsky K, Sfez S, Tagle DA, Ziv Y, Sartiel A, Collins FS, Shiloh Y, Rotman G. 1995. The complete sequence of the coding region of the ATM gene reveals similarity to cell cycle regulators in different species. Hum Mol Genet 4: 2025-2032.

Schmid C, Isaacson PG. 1994. Proliferation centres in B-cell malignant lymphoma, lymphocytic (B-CLL): An immunophenotypic study. Histopathology 24: 445-451.

Schreiber RD, Old LJ, Smyth MJ. 2011. Cancer immunoediting: Integrating immunity's roles in cancer suppression and promotion. Science 331: 1565-1570.

Schuh A, Becq J, Humphray S, Alexa A, Burns A, Clifford R, Feller SM, Grocock R, Henderson S, Khrebtukova I, et al. 2012. Monitoring chronic lymphocytic leukemia progression by whole genome sequencing reveals heterogeneous clonal evolution patterns. Blood 120: 4191-4196.

Schumacher TN, Schreiber RD. 2015. Neoantigens in cancer immunotherapy. Science 348: 69-74.

Schuster SJ, Neelapu SS, Gause BL, Janik JE, Muggia FM, Gockerman JP, Winter JN, Flowers CR, Nikcevich DA, Sotomayor EM, et al. 2011. Vaccination with patient-specific tumor-derived antigen in first remission improves disease-free survival in follicular lymphoma. J Clin Oncol 29: 2787-2794.

Seliger B, Ritz U, Abele R, Bock M, Tampé R, Sutter G, Drexler I, Huber C, Ferrone S. 2001. Immune escape of melanoma: First evidence of structural alterations in two distinct components of the MHC class I antigen processing pathway. Cancer Res 61: 8647-8650.

Seliger B, Cabrera T, Garrido F, Ferrone S. 2002. HLA class I antigen abnormalities and immune escape by malignant cells. Semin Cancer Biol 12: 3-13.

Sensi M, Anichini A. 2006. Unique tumor antigens: Evidence for immune control of genome integrity and immunogenic targets for $\mathrm{T}$ cell-mediated patient-specific immunotherapy. Clin Cancer Res 12: 5023-5032.

Shankaran V, Ikeda H, Bruce AT, White JM, Swanson PE, Old LJ, Schreiber RD. 2001. IFN $\gamma$ and lymphocytes prevent primary tumour development and shape tumour immunogenicity. Nature 410: 1107-1111.

Sherry B, Jain P, Chiu PY, Leung L, Allen SL, Kolitz JE, Rai KR, Barrientos J, Liang S, Hawtin R, et al. 2015. Identification and characterization of distinct IL-17F expression patterns and signaling pathways in chronic lymphocytic leukemia and normal B lymphocytes. Immunol Res 63: 216-227.

Shukla SA, Rooney MS, Rajasagi M, Tiao G, Dixon PM, Lawrence MS, Stevens J, Lane WJ, Dellagatta JL, Steelman S, et al. 2015. Comprehensive analysis of cancer-associ- 
ated somatic mutations in class I HLA genes. Nat Biotechnol 33: 1152-1158.

Smyth MJ, Thia KY, Street SE, Cretney E, Trapani JA, Taniguchi M, Kawano T, Pelikan SB, Crowe NY, Godfrey DI 2000. Differential tumor surveillance by natural killer (NK) and NKT cells. J Exp Med 191: 661-668.

Stevenson FK, Krysov S, Davies AJ, Steele AJ, Packham G. 2011. B-cell receptor signaling in chronic lymphocytic leukemia. Blood 118: 4313-4320.

Street SEA, Trapani JA, MacGregor D, Smyth MJ. 2002. Suppression of lymphoma and epithelial malignancies effected by interferon $\gamma$. J Exp Med 196: 129-134.

Sun Y, Sijts AJAM, Song M, Janek K, Nussbaum AK, Kral S, Schirle M, Stevanovic S, Paschen A, Schild H, et al. 2002. Expression of the proteasome activator PA28 rescues the presentation of a cytotoxic T lymphocyte epitope on melanoma cells. Cancer Res 62: 2875-2882.

Teng MWL, Vesely MD, Duret H, McLaughlin N, Towne JE, Schreiber RD, Smyth MJ. 2012. Opposing roles for IL-23 and IL-12 in maintaining occult cancer in an equilibrium state. Cancer Res 72: 3987-3996.

Teng MWL, Galon J, Fridman W-H, Smyth MJ. 2015. From mice to humans: Developments in cancer immunoediting. J Clin Invest 125: 3338-3346.

Till KJ, Lin K, Zuzel M, Cawley JC. 2002. The chemokine receptor CCR7 and $\alpha 4$ integrin are important for migration of chronic lymphocytic leukemia cells into lymph nodes. Blood 99: 2977-2984.

Topalian SL, Hodi FS, Brahmer JR, Gettinger SN, Smith DC, McDermott DF, Powderly JD, Carvajal RD, Sosman JA, Atkins MB, et al. 2012. Safety, activity, and immune correlates of anti-PD-1 antibody in cancer. N Engl J Med 366: 2443-2454.

Tran E, Ahmadzadeh M, Lu Y-C, Gros A, Turcotte S, Robbins PF, Gartner JJ, Zheng Z, Li YF, Ray S, et al. 2015. Immunogenicity of somatic mutations in human gastrointestinal cancers. Science 350: 1387-1390.

Van Allen EM, Miao D, Schilling B, Shukla SA, Blank C, Zimmer L, Sucker A, Hillen U, Foppen MHG, Goldinger SM, et al. 2015. Genomic correlates of response to CTLA4 blockade in metastatic melanoma. Science 350: $207-$ 211.

Van den Hove LE, Van Gool SW, Vandenberghe P, Boogaerts MA, Ceuppens JL. 1998. CD57 $/ \mathrm{CD} 28^{-} \mathrm{T}$ cells in untreated hemato-oncological patients are expanded and display a Th1-type cytokine secretion profile, ex vivo cytolytic activity and enhanced tendency to apoptosis. Leukemia 12: 1573-1582.

van Sandick JW, Boermeester MA, Gisbertz SS, ten Berge IJM, Out TA, van der Pouw Kraan TCTM, van Lanschot JJB. 2003. Lymphocyte subsets and $T_{h} 1 / T_{h} 2$ immune responses in patients with adenocarcinoma of the oesophagus or oesophagogastric junction: Relation to pTNM stage and clinical outcome. Cancer Immunol Immunother 52: 617-624.

Verheyden S, Ferrone S, Mulder A, Claas FH, Schots R, De Moerloose B, Benoit Y, Demanet C. 2009. Role of the inhibitory KIR ligand HLA-Bw4 and HLA-C expression levels in the recognition of leukemic cells by natural killer cells. Cancer Immunol Immunother 58: 855-865.
Coevolution of Leukemia and Host Immune Cells

Vesely MD, Kershaw MH, Schreiber RD, Smyth MJ. 2011. Natural innate and adaptive immunity to cancer. Annu Rev Immunol 29: 235-271.

Wahlfors J, Hiltunen H, Heinonen K, Hämäläinen E, Alhonen L, Jänne J. 1992. Genomic hypomethylation in human chronic lymphocytic leukemia. Blood 80: 20742080.

Wang L, Lawrence MS, Wan Y, Stojanov P, Sougnez C, Stevenson K, Werner L, Sivachenko A, DeLuca DS, Zhang L, et al. 2011. SF3B1 and other novel cancer genes in chronic lymphocytic leukemia. N Engl J Med 365: 2497-2506.

Wang J, Khiabanian H, Rossi D, Fabbri G, Gattei V, Forconi F, Laurenti L, Marasca R, Del Poeta G, Foà R, et al. 2014a. Tumor evolutionary directed graphs and the history of chronic lymphocytic leukemia. eLife 3: e02869.

Wang JQ, Jeelall YS, Beutler B, Horikawa K, Goodnow CC. 2014b. Consequences of the recurrent MYD $88^{L 265 P}$ somatic mutation for B cell tolerance. J Exp Med 211: 413-426.

Weiss L, Melchardt T, Egle A, Grabmer C, Greil R, Tinhofer I. 2011. Regulatory $\mathrm{T}$ cells predict the time to initial treatment in early stage chronic lymphocytic leukemia. Cancer 117: 2163-2169.

Woyach JA, Johnson AJ, Byrd JC. 2012. The B-cell receptor signaling pathway as a therapeutic target in CLL. Blood 120: $1175-1184$.

Yadav M, Jhunjhunwala S, Phung QT, Lupardus P, Tanguay J, Bumbaca S, Franci C, Cheung TK, Fritsche J, Weinschenk T, et al. 2014. Predicting immunogenic tumour mutations by combining mass spectrometry and exome sequencing. Nature 515: 572-576.

Zenz T, Eichhorst B, Busch R, Denzel T, Häbe S, Winkler D, Bühler A, Edelmann J, Bergmann M, Hopfinger G, et al. 2010. TP53 mutation and survival in chronic lymphocytic leukemia. J Clin Oncol 28: 4473-4479.

Zhang GL, Ansari HR, Bradley P, Cawley GC, Hertz T, Hu X, Jojic N, Kim Y, Kohlbacher O, Lund O, et al. 2011. Machine learning competition in immunology-Prediction of HLA class I binding peptides. J Immunol Methods 374: $1-4$.

Ziller MJ, Gu H, Müller F, Donaghey J, Tsai LT-Y, Kohlbacher O, De Jager PL, Rosen ED, Bennett DA, Bernstein BE, et al. 2013. Charting a dynamic DNA methylation landscape of the human genome. Nature 500: 477-481.

Zitvogel L, Tesniere A, Kroemer G. 2006. Cancer despite immunosurveillance: Immunoselection and immunosubversion. Nat Rev Immunol 6: 715-727.

Zorn E, Hercend T. 1999. A natural cytotoxic T cell response in a spontaneously regressing human melanoma targets a neoantigen resulting from a somatic point mutation. Eur J Immunol 29: 592-601.

Zucchetto A, Benedetti D, Tripodo C, Bomben R, Dal Bo M, Marconi D, Bossi F, Lorenzon D, Degan M, Rossi FM, et al. 2009. CD38/CD31, the CCL3 and CCL4 chemokines, and CD49d/vascular cell adhesion molecule-1 are interchained by sequential events sustaining chronic lymphocytic leukemia cell survival. Cancer Res 69: 4001-4009.

Zweidler-McKay PA, He Y, Xu L, Rodriguez CG, Karnell FG, Carpenter AC, Aster JC, Allman D, Pear WS. 2005. Notch signaling is a potent inducer of growth arrest and apoptosis in a wide range of B-cell malignancies. Blood 106: 3898-3906. 


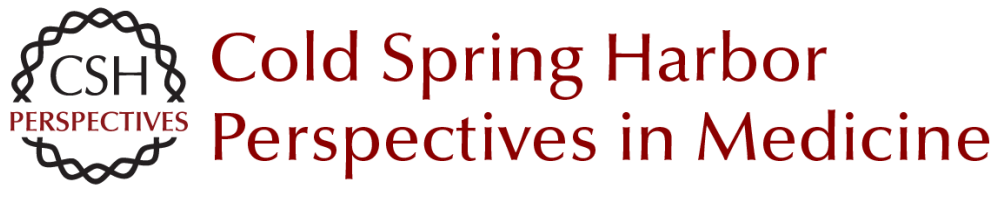

\title{
Coevolution of Leukemia and Host Immune Cells in Chronic Lymphocytic Leukemia
}

\author{
Noelia Purroy and Catherine J. Wu
}

Cold Spring Harb Perspect Med 2017; doi: 10.1101/cshperspect.a026740 originally published online January 17, 2017

\section{Subject Collection Cancer Evolution}

The Evolution and Ecology of Resistance in

Cancer Therapy

Robert A. Gatenby and Joel S. Brown

Big Bang Tumor Growth and Clonal Evolution Ruping Sun, Zheng Hu and Christina Curtis

Observing Clonal Dynamics across Spatiotemporal Axes: A Prelude to Quantitative Fitness Models for Cancer Andrew W. McPherson, Fong Chun Chan and Sohrab P. Shah

Evolution of Premalignant Disease Kit Curtius, Nicholas A. Wright and Trevor A. Graham

The Role of Aneuploidy in Cancer Evolution Laurent Sansregret and Charles Swanton

Treatment-Induced Mutagenesis and Selective Pressures Sculpt Cancer Evolution Subramanian Venkatesan, Charles Swanton, Barry S. Taylor, et al.

Chromosomal Instability as a Driver of Tumor Heterogeneity and Evolution Samuel F. Bakhoum and Dan Avi Landau

Coevolution of Leukemia and Host Immune Cells in Chronic Lymphocytic Leukemia

Noelia Purroy and Catherine J. Wu
The Evolution and Ecology of Resistance in Cancer Therapy

Robert Gatenby and Joel Brown

Phylogenetic Quantification of Intratumor Heterogeneity

Thomas B.K. Watkins and Roland F. Schwarz

The "Achilles' Heel" of Cancer and Its Implications for the Development of Novel Immunotherapeutic Strategies

Kroopa Joshi, Benjamin M. Chain, Karl S. Peggs, et al.

Homeostasis Back and Forth: An Ecoevolutionary Perspective of Cancer David Basanta and Alexander R.A. Anderson

Principles of Reconstructing the Subclonal

Architecture of Cancers Stefan C. Dentro, David C. Wedge and Peter Van Loo

Tumor Microenvironment and Differential

Responses to Therapy Eishu Hirata and Erik Sahai

Order Matters: The Order of Somatic Mutations Influences Cancer Evolution David G. Kent and Anthony R. Green

The Cellular Origin and Evolution of Breast Cancer Mei Zhang, Adrian V. Lee and Jeffrey M. Rosen

For additional articles in this collection, see http://perspectivesinmedicine.cshlp.org/cgi/collection/ 